\title{
ОБЛИЧЧЯ СМЕРТІ: ТЕРОР ПОЛЦЦЇ БЕЗПЕКИ ТА СД ПРОТИ НАСЕЛЕННЯ ГЕНЕРАЛЬНОЇ ОКРУГИ «МИКОЛАЇВ»
}

\section{РОЗДІЛ 2. ЖИТТЯ ТА СМЕРТЬ У ОКУПОВАНІЙ НАЦИСТАМИ УКРАÏHI}

\footnotetext{
Уперше детально розкривається структура і кадровий склад апарату Управління поліції безпеки та СД генеральної округи «Миколаїв», його роль у масштабному терорі проти цивільного населення регіону. Віднайдені конкретні прізвища співробітників керівного і рядового складу, які були ініціаторами чи безпосередньо причетними до арештів, катувань, конвоювання під час масових розстрілів і показових страт. Висвітлюються основні способи вербування, а також механізм створення розгалуженої агентурної мережі із місиевих колаборантів. Уточнені місия і процедура деяких страт єврейського і ромського населення. Вводяться до наукового обігу світлина другого шефа Управління поліиії безпеки та СД генеральної округи «Миколаїв» штурмбанфюрера СС д-ра Леопольда Шпанна та фото інших співробітників нацистської спецслужби. Оприлюднено креслення місцерозташування основних будівель штаб-квартири поліції безпеки та СД у Миколаєві, схеми місць масових розстрілів. Складено поіменний список зондеркоманди, учасники якої займались ліквідацією слідів злодіянь співробітників досліджуваної окупаційної спецслужби в 1943-1944 рр. З'ясовано подальший маршрут руху співробітників поліції безпеки та СД після евакуації з Миколаїва в березні 1944 р.

Ключові слова: Миколаїв, поліція безпеки та СД, терор, цивільне населення, рух Опору, єврейське і ромське населення, колаборація, Голокост.

Після окупації України м. Миколаїв стало центром генеральної округи «Миколаїв» (Generalbezirk Nikolajew) у складі Райхскомісаріату «Україна». Із приходом гітлерівських військ і встановленням «нового порядку» в регіоні одразу розпочався масовий терор представниками поліції безпеки та СД, іншими каральними структурами. Упродовж тривалого часу в науковій літературі згадувались лише окремі прізвища співробітників досліджуваної регіональної окупаційної спецслужби в контексті їх протистояння з представниками місцевих рухів Опору, у більшості випадків - використовувався узагальнений образ «нацистських карателів», не були відомі важливі деталі про конкретну
} 
участь і безпосередніх виконавців тих чи інших масових злочинів, що відбувались на території Миколаївщини в період 1941-1944рp.

Аналіз наукової літератури засвідчив відсутність спеціальних наукових публікацій, присвячених дослідженню структури апарату і кадрового складу Управління поліції безпеки та СД генеральної округи «Миколаїв» в 1941-1944 рр. Серед науково-популярних праць місцевих краєзнавців, які в контексті висвітлення підпільнопартизанського руху чи наслідків терору окремих нацистських загарбників деякою мірою торкались досліджуваного автором аспекту, можна згадати роботи В. Чуніхіна ${ }^{1}$, Є. Горбурова та К. Горбурова ${ }^{2}$. Більш предметно загальну мережу нацистських органів безпеки на території Райсхкомісаріату «Україна» та інших окупованих регіонів СРСР досліджували І. Дерейко ${ }^{3}$, С. Чуєв ${ }^{4}$.

Автор ставить за мету розкрити структуру апарату і кадровий склад Управління поліції безпеки та СД генеральної округи «Миколаїв», його ролі у системі терору проти населення регіону; висвітлити способи вербування агентів та інформаторів із місцевих колаборантів для виявлення та ліквідації представників місцевого руху Опору, представників етнічних груп, які не були страчені в перші місяці окупації; оприлюднити конкретні прізвища співробітників керівного і рядового складу, які були ініціаторами чи безпосередньо причетні до масових арештів, катувань, розстрілів, а також схему місцерозташування «робочих кабінетів», камер смертників та інших приміщень Управління поліції безпеки та СД, місць і процедури масових розстрілів населення, у тому числі євреїв і ромів.

Основою для написання статті стали розсекречені документи колишнього КДБ, що зберігаються в Галузевому державному архіві Служби безпеки України (ГДА СБУ, м. Київ), а також у Секторі архівного забезпечення Управління Служби безпеки України в Миколаївській області (САЗ УСБУ в Миколаївській області). Це матеріали архівно-слідчих справ, судових процесів над нацистськими

$\overline{1}$ Владимир Чунихин, Лицом к лицу с СД (Одесса: Маяк, 1987); Владимир Чунихин, Невидимой армии добровольцы (Николаев: КП «Миколаївська обласна друкарня», 2004).

${ }^{2}$ Евгений Горбуров і Кирилл Горбуров, Николаевский «Нюрнберг». Судебный процесс по делу о немецко-фашистских зверствах в г. Николаеве и Николаевской области 10-17 января 1946 года о немецко-фашистских зв

${ }^{3}$ Іван Дерейко, «Місцеві допоміжні структури та військові формування поліції безпеки та СД на теренах Райсхкомісаріату “Україна”: 1941-1944», Сторінки воєнної історії України: зб. наук. ст. 12 (2009): $177-184$.

${ }^{4}$ Сергей Чуев, Спецслужбы Третьего Рейха, книга II (Санкт-Петербург: Издательский дом «Нева»; Москва: «ОЛМА-ПРЕСС Образование», 2003). злочинцями та ін. Найбільш інформативними є виявлені автором фрагменти перекладу власних свідчень першого шефа Миколаївського окружного управління поліції безпеки та СД Ганса Занднера, розлогі допити штатних перекладачів, окремих вахманів (шуцманів) та водіїв СД.

\section{Участь Г. Занднера ${ }^{5}$ в масових розстрілах у Бабиному Яру і його}

призначення шефом поліції безпеки та СД генеральної округи «Миколаїв"

Першою командою поліції безпеки, яка прибула до Миколаєва в період воєнних дій, була бойова команда айнзатцгрупи D. «Ефективність» діяльності мобільних (похідних) підрозділів айнзатцгрупи D під командуванням штандартенфюрера СC Отто Олендорфа протягом серпня - початку жовтня 1941 р. призвела до майже поголовного знищення єврейського населення. Ці дані доволі детально відображені в різних наукових публікаціях ${ }^{6}$. Проте системне знищення залишків «політично небезпечних елементів» тривало протягом усього періоду окупації вже штатним апаратом поліції безпеки та СД генеральної округи «Миколаїв», іншими каральними органами.

32 листопада 1941 до 20 березня 1942 р. тимчасовим начальником оперативної команди поліції безпеки та СД генеральної округи «Миколаїв» був оберштурмфюрер СС Ганс Занднер ${ }^{7}$. 320 березня 1942 до серпня 1943 р. Управління поліції безпеки та СД очолював штурмбанфюрер СС доктор Леопольд Шпанн (родом із м. Лінц, Австрія). Після переведення доктора Шпанна в Саарбрюккен Управління очолив оберштурмфюрер СС Фрідріх Хегеншайд, який залишався на цій посаді до евакуації всіх співробітників управління в березні 1944 р. із Миколаєва до Одеси ${ }^{8}$.

\footnotetext{
5 у деяких публікаціях зустрічається як Санднер.
}

${ }_{6}^{6}$ Александр Круглов, Без жалости и сомнения: документы о преступлениях оперативных групп и команд полиции безопасности и СД на временно оккупированной территории СССР в 1941 1944 гг., ч. IV (Днепропетровск: Центр «Ткума»; Лира ЛтД, 2010); Михаил Гольденберг, ред., Судьбы евреев Николаевщины в период Великой Отечественной войны 1941-1945 гг. (Николаев: Издатель П. Н. Шамрай, 2012); Микола Шитюк, «Знищення єврейського населення в Південній «Історична пам'ять про війну та Голокост», Київ, 28-30 вересня 2012 р. (Дніпропетровськ: Центр «Ткума», 2013), 195-215; Валерій Васильєв, Наталя Кашеварова, Олена Лисенко, Марія Панова і Роман Подкур, авт.-укл., Насильство над цивільним населенням України. Документи спецслужб. 1941-1944 (Київ: Видавець В. Захаренко, 2018).

7 Сектор архівного забезпечення Управління Служби безпеки України в Миколаївській області (далі - САЗ УСБУ в Миколаївській області), ф. 5, оп. 1, спр. 13204, т. 7, арк. 308.

8 Чуев, Спецслужбы Третьего Рейха, 71. 
Ганс Занднер отримав призначення на відповідну посаду в Миколаєві не одразу9 .25 вересня 1941 р. він разом з 8-10 товаришами по службі спочатку прибув до Києва ${ }^{10}$. Серед цієї команди було кілька осіб, які навчалися з ним з 20 травня 1940 до 21 лютого 1941 р. у школі командного складу поліції безпеки в Берлін-Шарлоттенбурзі: унтерштурмфюрер СС Теодор Зальманціг ${ }^{11}$ (співробітник кримінальної поліції м. Гамбурга), унтерштурмфюрер СС Ганс-Йоахім Зоммерфельд ${ }^{12}$ (співробітник головного управління кримінальної поліції м. Берліна), унтерштурмфюрер СС Ганс Юнке ${ }^{13}$ (співробітник кримінальної поліції м. Штеттіна). Керівником цієї групи був штурмбанфюрер Герман Лінг ${ }^{14}-$ співробітник СД м. Бреслау, який до того часу служив у Норвегії при управлінні поліції безпеки та СД м. Тронхейма $^{15}$. Він також був направлений в айнзатцгрупу С в Київ.

Наступного дня після прибуття вказана група офіцерів була представлена начальнику поліції безпеки та СД України бригаденфюреру СС доктору Отто Рашу. У цей час доктор Раш ще був шефом айнзатцгрупи С в Україні, але його кандидатура висувалась на посаду начальника поліції безпеки та СД м. Москви після її захоплення німецькими військами. Під час наради доктор Раш повідомив підлеглих, що орієнтовно через декілька днів ${ }^{16}$ після їх приїзду вони мають бути присутніми на великому каральному заході - масовому розстрілі євреїв (акція в Бабиному Яру). До того ж заявив, що офіцерам СС доведеться

\footnotetext{
${ }_{9}^{9}$ Інформація про прибуття Ганса Занднера у Київ, особисту присутність під час розстрілу єврейського населення в Бабиному Яру, причини переведення у Миколаїв - це фрагмент переєврейського населення в Бабиному Яру, причини переведення у Миколаїв - це фрагмент пере
кладу протоколу його особистих свідчень. Вочевидь, деякі дати в його свідченнях переплутані, оскільки найбільш масові страти відбулися 29-30 вересня, а не на початку жовтня 1941 p.

10 Автор висловлює подяку Олександру Круглову за ряд уточнень правильності написання окремих населених пунктів, прізвищ та звань нацистських злочинців. У документі серед новоприбулих у Київ помилково згадується унтерштурмфюрер СС Конрад Фібіг (кримінальна поліція м. Катовіце). у Киів помилково згадується унтерштурмфюрер СС Конрад Фібіг (кримінальна поліція м. Катовіце),
Ганс Занднер справді навчався з ним у школі фюрерів поліції безпеки у Берлін-Шарлоттенбурзі, проте унтерштурмфюрер СС К. Фібіг потрапив до айнзатцгрупи В, а не до айнзатцгрупи С.

11 У документі помилково зазначено Тео Шванциг. Правильно - унтерштурмфюрер СС Теодор Зальманціг (Theodor Salmanzig).

12 У документі помилково вказано Карл Зоммерфельд, правильно - Ганс-Йоахім Зоммерфельд.

13 У документі помилково вказано Ганц Юліке. Правильно - Ганс Юнке (Hans Juhnke).

14 У документі помилково зазначено Герман Бірк. Правильно - штурмбанфюрер СС Герман Лінг (Hermann Ling).

15 У документі помилково зазначено м. Осло.

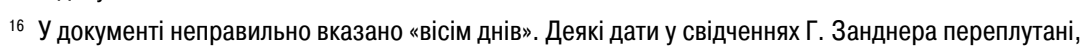
оскільки найбільш масові страти відбулись 29-30 вересня, а не на початку жовтня 1941 p. звикати до таких «видовиш» ${ }^{17}$, хоч це жорстоко і «не особливо естетично», але такі заходи цілком необхідні і $є$ частиною політики «дії».

Для спланованого нацистами масового винищення єврейського населення та пограбування його майна по Києву були розклеєні афіші з оголошенням про те, шо всі євреї мають з'явитись у визначений час в один з провулків поблизу Київського кладовища. Збір єврейського населення мотивувався «евакуацією». Люди мали принести із собою золото та інші коштовності. Таким чином, нацистські злочинці позбавляли себе необхідності нишпорити по квартирах у пошуках цих цінних речей. Для проведення згаданого «заходу» євреї упродовж 29-30 вересня ${ }^{18}$ були під різними приводами зібрані у визначене місце. За спостереженнями Ганса Занднера, на збірні пункти з'явилось близько 20 тис. осіб. Керівником розстрілу був оберштурмфюрер СC Хефнер ${ }^{19}$. Вказана кількість євреїв засвідчує, що Ганс Занднер був присутнім під час масових розстрілів саме 29 вересня 1941 р., а не «2-5 жовтня» 1941 р., як він зазначає у власних свідченнях.

Оскільки й нині відсутні повні дані про конкретні місця розстрілів, дуже важливою деталлю є інформація про те, що розстріли під час «грос акції» проводились одночасно в чотирьох місцях. Вивчення досвіду «операції, яку проводив Хефнер, потрібно було вказаній групі офіцерів СС для того, аби вони могли навчитись самостійно керувати такими ж розстрільними акціями в «найближчому майбутньому» ${ }^{20}$.

Нині відомо, що з початку жовтня і до середини листопада 1941 р. представники айнзатцкоманди 5 знищили 29835 осіб (96,5\% розстріляних становили євреї) ${ }^{21}$. У контексті цього вагомим аспектом є свідчення оберштурмфюрера СС Ганса Занднера про особисте керування масовим розстрілом євреїв 8-9 жовтня 1941 р., ${ }^{22}$ у процесі якого було знищено 800 осіб.

За час перебування Ганса Занднера в Києві там майже щоденно проводили розстріли 200-300 військовополонених, які утримувались

17 Галузевий державний архів Служби безпеки України (далі - ГДА СБУ), ф. 11, оп. 1, спр. 1043, т. 1, арк. 10.

18 у документі помилково зазначено «2-5 жовтня».

19 у документі помилково вказано Август Гофер. Правильно - оберштурмфюрер СС Август ХЕФHEP (August HÄFNER).

20 ГДА СБУ, ф. 11, оп. 1, спр. 1043, т. 1, арк. 11.

${ }_{21}$ Владислав Гриневич і Павло-Роберт Магочій, ред., Бабин Яр: Історія та пам'ять (Київ: Дух і Літера, 2017), 99

22 Оскільки аналіз документа показує, що висвітлення Гансом Занднером хронології подій у Бабиному Яру помилково відбувається з різницею в декілька днів, то, імовірно, і ця дата є дещо неточною. 
у таборі ${ }^{23}$. Імовірно, мова йде про табір для військовополонених, що розташовувався на вул. Керосинній (нині - вул. Шолуденка), у якому було окреме відділення для тимчасового утримання євреїв та політпрацівників ${ }^{24}$. Крім того, окремі пошуки проводились у місцевих лікарнях, де відбирали євреїв та одразу ж знищували ${ }^{25}$ (мова йде про євреїв-душевнохворих з лікарні імені І. Павлова).

Оскільки айнзатцгрупи були тимчасовими формуваннями, то після виконання завдань зі знищення визначеного кола політичних ворогів з окремих підрозділів формувались місцеві стаціонарні штабквартири поліції безпеки та СД. Загальновідомо, що на базі згаданої айнзатцкоманди 5 сформовано службу начальника поліції безпеки та СД для генеральної округи «Київ» ${ }^{26}$. На відміну від своїх «колег» Ганс Занднер у Києві пробув недовго. Приблизно 21 жовтня 1941 р. із Миколаєва був отриманий запит про відправку туди «команди». Ганс Занднер у той час ще перебував у підпорядкуванні айнзатцкоманди штурмбанфюрера СС Майєра (до того - шеф СД м. Троппау ${ }^{27}$ ). Через те, що посади начальників команд поліції безпеки та СД були вже розподілені й завдяки знанню румунської мови, саме йому було наказано відправитись $з$ командою в Миколаїв. Для вивчення ситуації на місці він попередньо поїхав до міста з чотирма співробітниками на двох автомашинах. Прибувши у Миколаїв орієнтовно 24 жовтня 1941 р., Ганс Занднер застав там залишки команди під керівництвом унтерштурмфюрера СC Фішера ${ }^{28}$ (частина айнзатцгрупи D). Два дні потому Ганс Занднер повернувся до Києва, щоб забрати решту людей 3 його команди та доповісти про ситуацію штурмбанфюреру СС Майєру. Пробувши в Києві два дні, Ганс Занднер виїхав із десятьма співробітниками і прибув до Миколаєва 2 листопада 1941 р. Попередньо ознайомившись зі справами, він прийняв командування від унтерштурмфюрера СС Фішера ${ }^{29}$.

\footnotetext{
23 ГДА СБУ, ф. 11, оп. 1, спр. 1043, т. 1, арк. 11.

${ }_{24}$ Гриневич і Маґочій, ред., Бабин Яр, 93

25 ГДА СБУ, ф. 11, оп. 1, спр. 1043, т. 1, арк. 11.

${ }_{26}$ Гриневич і Маґочій, ред., Бабин Яр, 78

${ }^{27}$ Август Майєр був керівником СД в м. Троппау/Опава (Судети) 3 жовтня 1938 р. 3 лютого 1941 р. він очолював СД у м. Лігніц (Сілезія).

${ }^{28}$ Мова йде про унтерштурмфюрера СС Карла Фішера, який у кінці вересня 1941 р. був відряджений до айнзатцгрупи D. До відрядження - інструктор зі спорту у школі фюрерів поліції
} безпеки в Берлін-Шарлоттенбурзі.

${ }^{29}$ САЗ УСБУ в Миколаївській області, ф. 5, оп. 1, спр. 13204, т. 7, арк. 308

Масовий терор поліції безпеки та СД проти місцевого населення на чолі з Гансом Занднером

Штаб-квартира поліції безпеки та СД генеральної округи «Миколаїв» розташовувалась у м. Миколаєві на вул. Велика Морська в будинках № 26, 28 і 30 (за старою, довоєнною нумерацією). Польова пошта № 4789030. Нині -це ряд будинків на вул. Велика Морська, 52-56/9, що збереглись у міському кварталі між вул. Наварінською та Пушкінською.

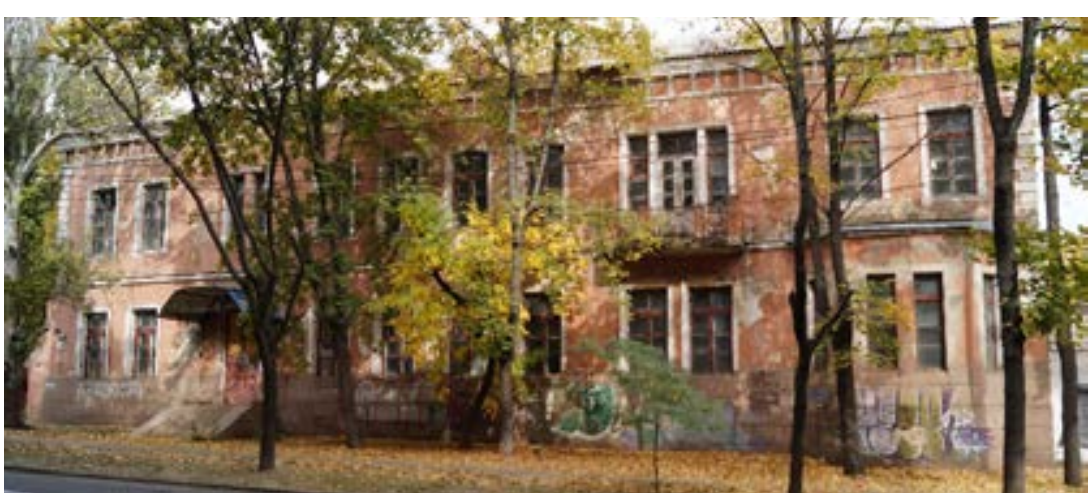

На другому поверсі цієі будівлі розташовувались житлові кімнати офіцерів і слідчих поліції безпеки та СД, на першому - їдальня для імперських німців. На плані Івана Бернгардта (фольксдойче) автор позначив їі номером IV. У післявоєнний період тут розміщувався обласний туберкульозний диспансер. 3 1960-х і до лютого 2010 р. - друга міська лікарня. Нині будівля перебуває в занедбаному аварійному стані (м. Миколаїв, жовтень 2018 р., автор фото - А. Погорєлов).

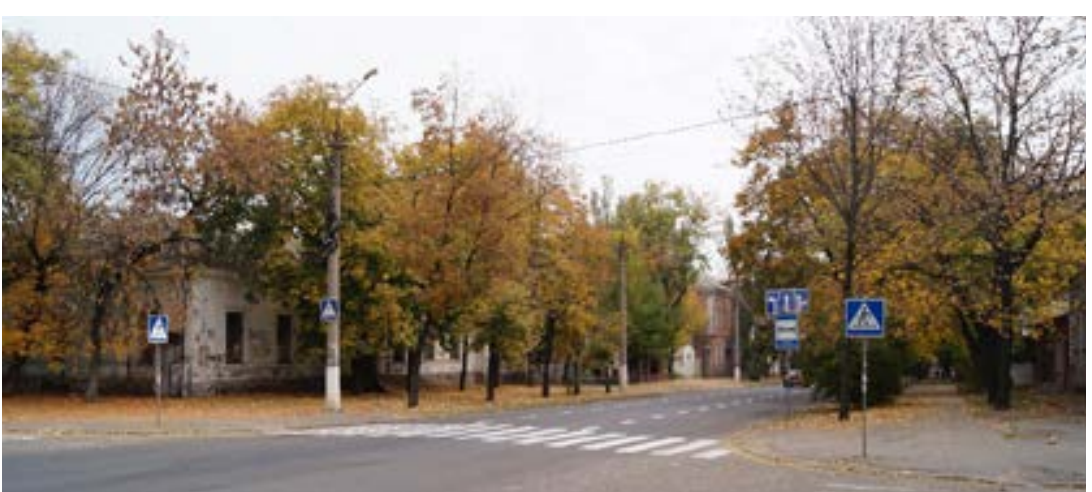

«Квартал поліції безпеки та СД» розташовувався на вул. Велика Морська між вул. Наварінською та Пушкінською (м. Миколаїв, жовтень 2018 р., автор фото - А. Погорєлов).

30 ГДА СБУ, ф. 11, оп. 1, спр. 1043, т. 1, арк. 37. 


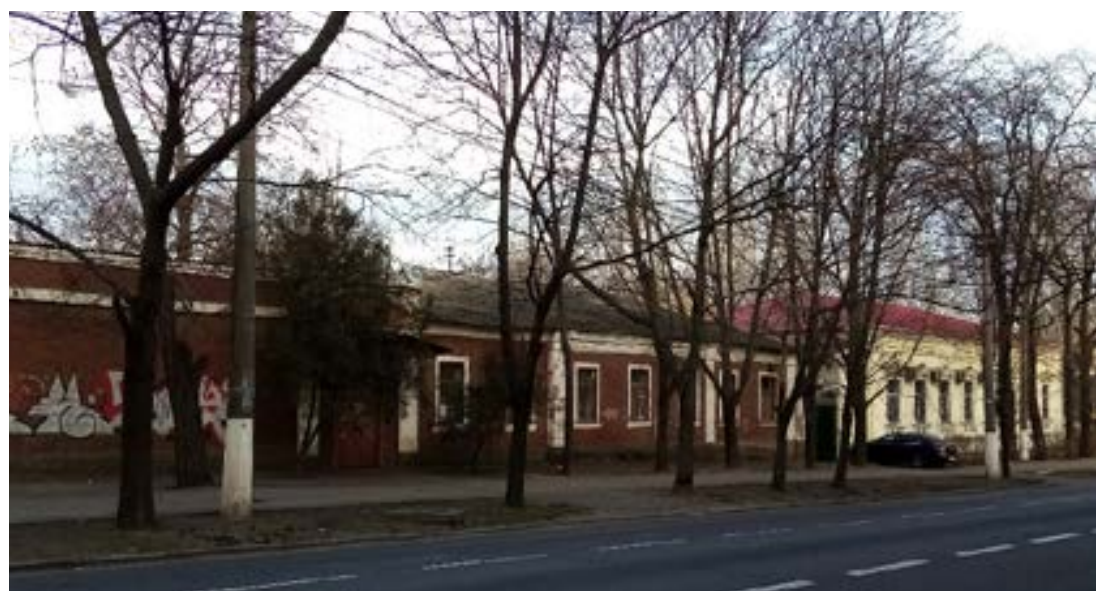

у невеликій коричневій будівлі (ліворуч) розміщувались робочі кабінети слідчих поліції без пеки та СД. На схемі I. Бернгардта автор позначив їI номером II. У будівлі із жовтим фасадом (праворуч) розташовувались кабінети шефів Управління поліції безпеки та СД генеральної округи «Миколаїв» - Г. Занднера, Л. Шпанна, Ф. Хегеншайда, приймальня, канцелярія та ін. На схемі І. Бернгардта автор позначив іï номером I (м. Миколаїв, січень 2020 р., автор фото - А. Погорєлов)

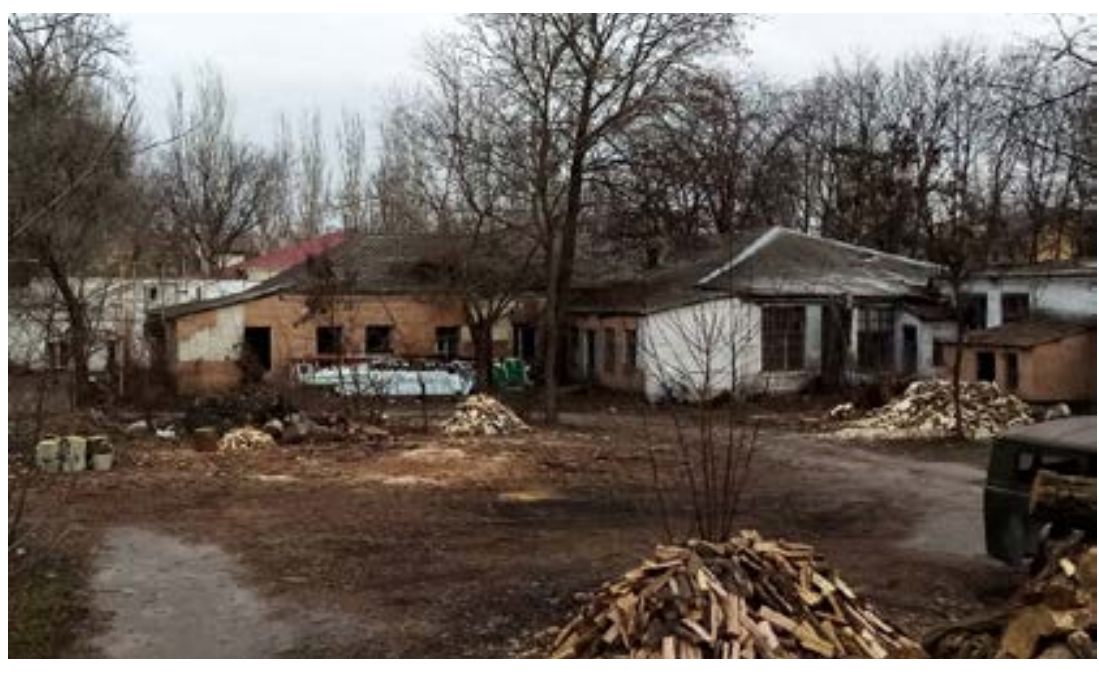

Фрагмент внутрішньої території колишнього Управління поліції безпеки та СД генеральної округи «Миколаїв». У зображеній занедбаній будівлі розташовувались робочі кабінети слідчих поліції безпеки та СД. На схемі І. Бернгардта автор позначив ії номером II (м. Миколаїв, січень 2020 р., автор фото - А. Погорєлов).
Детальніше уявити будівлі, в яких розташовувались співробітники поліції безпеки та СД, можна з такої схеми:

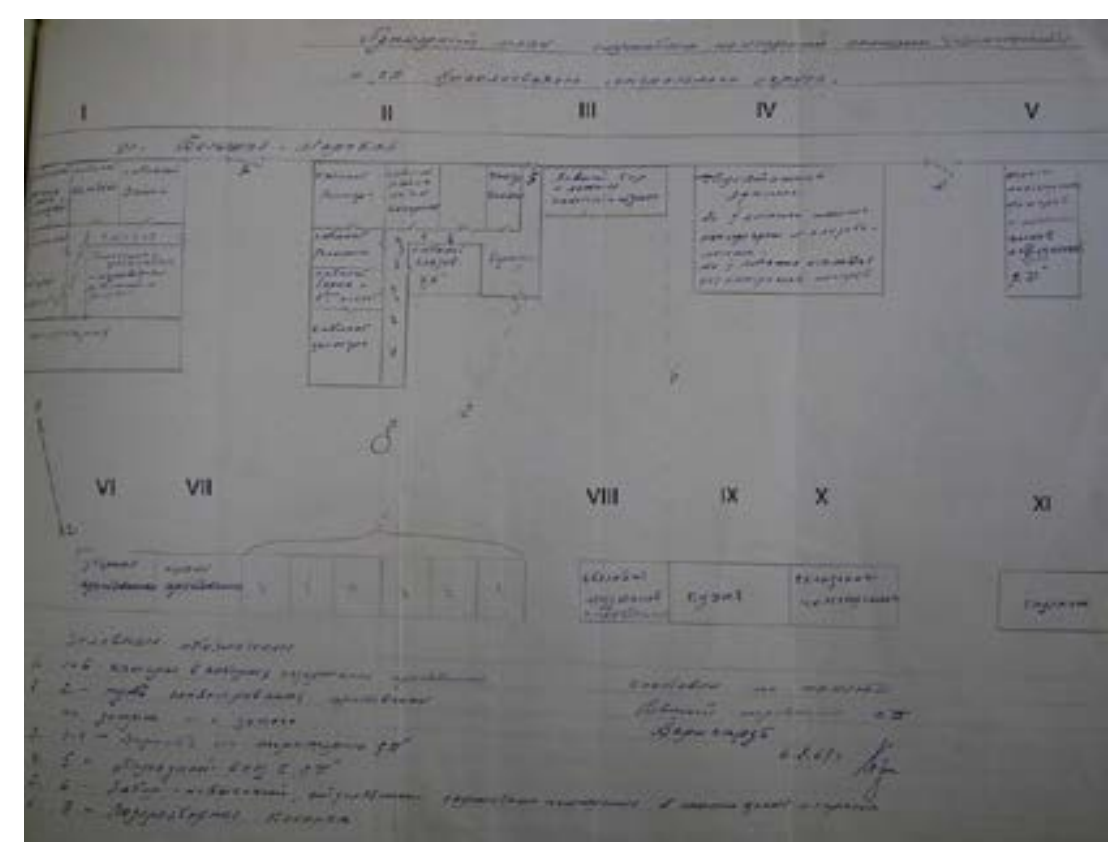

Детальна схема службових приміщень поліції безпеки та СД генеральної округи «Миколаїв» у період 1942-1944 рр. План складений колишнім співробітником (перекладачем) Управління поліції безпеки та СД генеральної округи «Миколаїв» I. Бернгардтом. 6 серпня 1969 р. Римські цифри нанесені А. Погорєловим для більш детального пояснення схеми ${ }^{31}$

Умовні позначення, нанесені Іваном Бернгардтом арабськими цифрами:

1-6 - камери, у яких утримувались арештовані громадяни;

2 - шлях конвоювання арештованих на допити та у зворотному напрямку;

3-4 - ворота для в їзду на територію СД;

5 - парадний вхід у СД;

6 - невисокий паркан, що відокремлював службові приміщення від житлової будівлі та гаражу;

7 - водозабірна колонка.

${ }^{31}$ САЗ УСБУ в Миколаївській області, ф. 5, оп. 1, спр. 13204, т. 2, арк. 361. 
Для детальнішого пояснення написів на вищевказаній схемі автор статті позначив римськими цифрами будівлі, у яких розташовувались:

I - кабінети шефів Управління поліції безпеки та СД генеральної округи «Миколаїв» - Г. Занднера, Л. Шпанна, Ф. Хегеншайда; приймальня і канцелярія; кабінети офіцерів Кальбаха (заступник шефа СД), доктора Вайса (начальник 1 відділу);

II - кабінети офіцерів СД Рьоппера, Вайса, Кокерольса, Реллінга, Горна, Ціммера та ін.;

III - пивний бар та літня кімната для відпочинку;

IV - двоповерхова будівля: на 1-му поверсі - їдальня для імперських німців, на 2-му - мешкали офіцери та слідчі;

V - житлові приміщення водіїв та нижчих за рангом співробітників СД;

VI - вбиральня для арештованих;

VII - кухня для арештованих;

VIII - їдальня для шуцманів і перекладачів;

IX - кухня;

$\mathrm{X}$ - складські приміщення;

XI - гараж.

Ознайомивши Ганса Занднера зі справами, унтерштурмфюрер СС Фішер передав йому 20 заарештованих представників радянської інтелігенції (головним чином, студентів, одного викладача) і 7 «бандерівців». Усіх мали відправити для подальшого утримання у Львові, але до цього справа так і не дійшла, тому зрештою всіх розстріляли.

Після від’ізду унтерштурмфюрера СС Фішера новопризначений шеф поліції безпеки та СД зайнявся облаштуванням реквізованих приміщень, звідки вигнав більшість місцевих німців та українців, які були для нього тягарем ${ }^{32}$. Спочатку штат складався з 15 співробітників та солдатів СС, одного радиста. Серед людей Ганса Занднера було багато «старих» службовців, які «чудово знали роботу», особливо $\mathrm{Pi}$ хард Бенке (співробітник кримінальної поліції м. Берліна) та Зигфрід Лампрехт (співробітник гестапо м. Хоензальца ${ }^{33}$, Польща) ${ }^{34}$. Саме гауптшарфюрер СС Бенке ${ }^{35}$ і став заступником Ганса Занднера в пер-

\footnotetext{
32 ГДА СБУ, ф. 11, оп. 1, спр. 1043, т. 1, арк. 12.

зз у документі помилково вказано Розензальц. Правильно - Хоензальца (Hohensalza). Зараз Іновроцлав (Польща).

34 ГДА СБУ, ф. 11, оп. 1, спр. 1043, т. 1, арк. 13, 91

35 у документі помилково зазначено штурмфюрер СС. Правильно - гауптшарфюрер СС Ріхард Бенке (Richard Behnke).
}

ші місяці його «роботи» ${ }^{36}$. Іншими співробітниками також були Хуго Зайферт ${ }^{37}$ (співробітник гестапо, мешканець м. Майсен), Людвіг Павель (співробітник Кріппо), Курт Майснер (співробітник гестапо, мешканець м. Баутцен) $)^{38}$.

У ролі зв'язкових і довірених осіб на «Північній верфі» (Суднобудівний завод імені 61 комунара) працював утерштурмфюрер СС Ноймайстер, на «Південній верфі» (Чорноморський суднобудівний завод) - унтерштурмфюрер СС Шеффер ${ }^{39}$. У січні 1942 р. із Головного управління кримінальної поліції Берліна до Миколаєва прибув штурмшарфюрер СС Рункель ${ }^{40}$, який обійняв посаду нового заступника шефа поліції безпеки та СД. 6 січня 1942 р. штурмфюрер СС Бенке був звільнений з посади та повернувся до кримінальної поліції м. Берліна ${ }^{41}$.

Приблизно 20 листопада 1941 р. в Миколаїв прибули співробітники охоронної поліції майор Вітцлеб та оберлейтенант Вайнгартен. Вони розташувались в іншій будівлі на вул. Великій Морській, що була реквізована поліцією безпеки та СД ${ }^{42}$. Потік арештованих хлинув із різних закладів: міського комісаріату, обласного комісаріату, заводів, місцевої комендатури та ін ${ }^{43}$.

Аналіз документів засвідчує основні напрями терору поліції безпеки та СД проти населення генеральної округи «Миколаїв» у 19411944 рр.: пошук та повне знищення залишків єврейського населення (зокрема членів змішаних родин); знищення ромського населення; психічно хворих людей; ліквідація організованого спротиву радянського та націоналістичного підпілля; знищення частини військовополонених у концтаборі «Шталаг 364» (комісарів, членів комуністичної партії, євреїв-військовополонених); покарання шляхом побиття чи грошових штрафів за будь-яке порушення «нового порядку»; показові страти на шибениці в центрі Миколаєва; ув'язнення на різні терміни в Миколаївській центральній в'язниці СД, у концтаборі СД для цивільних осіб «Водокачка» (розташовувався на відстані 35 км від

${ }^{36}$ ГДА СБУ, ф. 11, оп. 1, спр. 1043, т. 1, арк. 15.

${ }_{37}$ У документі помилково вказано Гуго Сайфірд. Правильно - штурмман СС Хуго Зайферт (Hugo Seifert).

38 ГДА СБУ, ф. 11, оп. 1, спр. 1043, т. 1, арк. 91.

39 ГДА СБУ, ф. 11, оп. 1, спр. 1043, т. 1, арк. 13.

40 У документі помилково зазначено Рункельд. Правильно - Рункель.

41 ГДА СБУ, ф. 11, оп. 1, спр. 1043, т. 1, арк. 17.

42 ГДА СБУ, ф. 11, оп. 1, спр. 1043, т. 1, арк. 15.

43 ГДА СБУ, ф. 11, оп. 1, спр. 1043, т. 1, арк. 13. 
міста); депортація «засуджених» для відбування покарань у концтаборі Бухенвальд, Равенсбрюк та ін.

Згідно із свідченнями колишнього вахмана СД Олександра Грози, найбільш масові розстріли населення були в 1941 - на початку 1942 p. У 1943-1944 рр. співробітники поліції безпеки та СД арештованих громадян розстрілювали менше, оскільки після допитів і катувань більшість відправляли на рабську працю в концтабори Німеччини ${ }^{44}$. Негласні розстріли в Миколаєві проводились кожного тижня. Спеціальні військовівантажівки вивозили в середньому по 15-20 осіб (в окремих випадках близько сотні), яких розстрілювали в спеціально підготовлених ямах чи протитанкових ровах неподалік від старого Єврейського кладовища, згодом - біля стін концтабору для радянських військовополонених «Шталаг 364», а також біля тюрми СД (сучасна територія Миколаївського СІЗО).

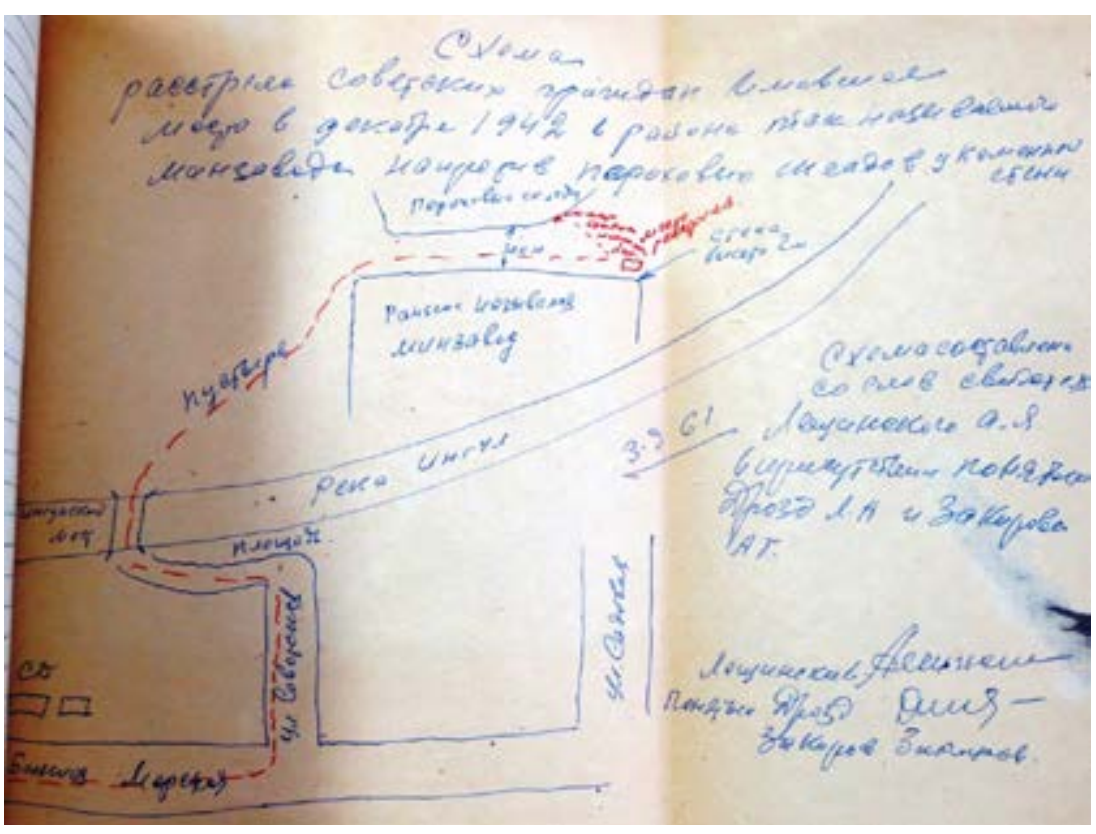

Схема місця розстрілу радянських громадян, що відбувся у грудні 1942 р. в районі так званого Мінзаводу навпроти порохових складів біля кам'яної стіни. Схема складена зі слів водія Управління поліції безпеки та СД генеральної округи “Миколаїв» Адольфа Лещинського (фольксдойче, див. фото нижче). 3 вересня 1961 р.45

${ }_{44}$ САЗ УСБУ в Миколаївській області, ф. 5, оп. 1, спр. 13204, т. 2, арк. 24 зв.

45 САЗ УСБУ в Миколаївській області, ф. 5, оп. 1, спр. 13204, т. 3, арк. 241.

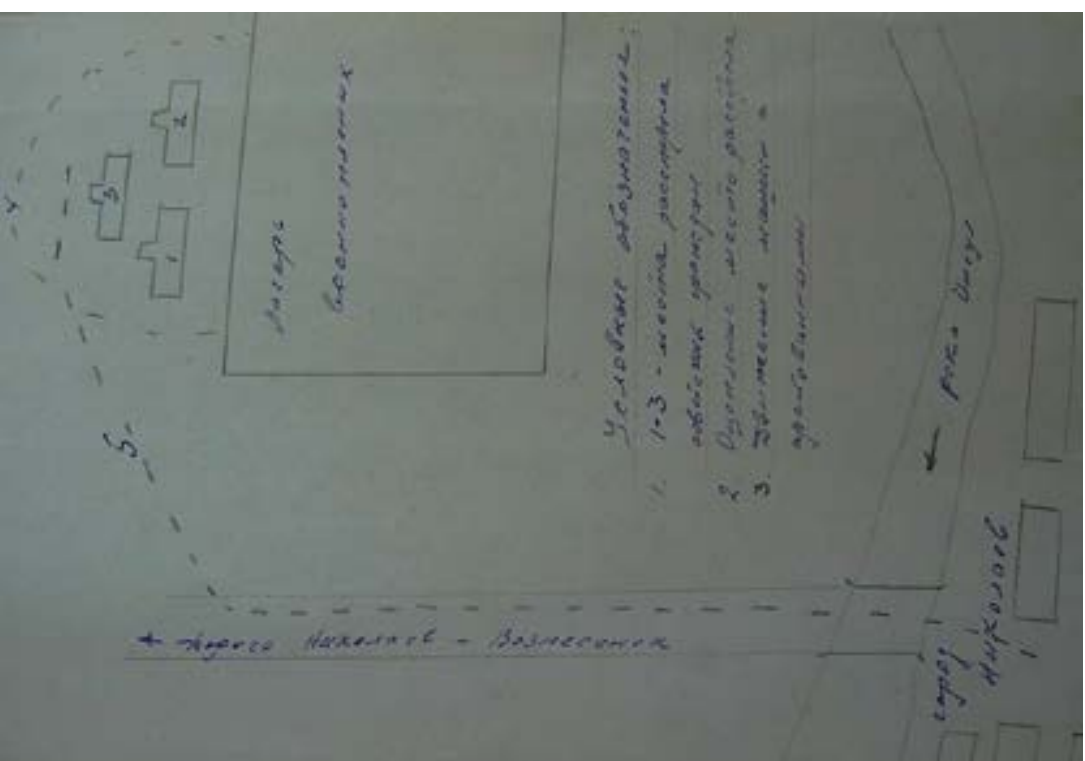

Орієнтовна схема масових розстрілів радянських громадян біля стін концтабору «Шталаг 364». План складений колишнім перекладачем Управління поліції безпеки та СД генеральноі округи «Миколаїв» Іваном Бернгардтом (фольксдойче, див. фото нижче). 6 серпня 1969 р.46

Для розстрілу радянських громадян виділялась група співробітників СД. Якоїсь постійної команди, яка б займалась лише вбивством громадян, у 1941-1943 рр. у поліції безпеки та СД не було. Кожного разу склад групи, яка виїздила на розстріли, змінювався. У дні страти арештованих громадян співробітники СД звільнялись від будь-якої іншої «роботи» і займались лише організацією вбивств. На розстріли завжди виїздив шеф СД чи його заступник, два-три офіцери, дватри перекладачі, а кількість вахманів коливалась залежно від того, наскільки небезпечними були особи, які підлягали розстрілу (у середньому розстрільна команда нараховувала 30-50 осіб). До місця розстрілу громадян доставляли на вантажівках, вкритих брезентом. В Управлінні поліції безпеки та СД було чотири таких машини. На розстріл виїздили о 9-й чи 10-й годині ранку після сніданку. Після розстрілу всім учасникам розстрільної команди знову влаштовували гарний сніданок з обов'язковою видачею горілки, вина та пива ${ }^{47}$.

\footnotetext{
${ }^{46}$ САЗ УСБУ в Миколаївській області, ф. 5, оп. 1, спр. 13204, т. 2, арк. 360.

${ }_{47}$ САЗ УСБУ в Миколаївській області, ф. 5, оп. 1, спр. 13204, т. 2, арк. 24 зв., 25.
} 
За період керівництва Ганса Занднера штат поліції безпеки та СД генеральної округи «Миколаїв» Знищив таку кількість населення ${ }^{48}$ :

- у листопаді 1941 р. розстріляно 150 євреїв, 80 радянських активістів та членів комуністичної партії, різних «шкідників», 80 військовополонених із табору ${ }^{49}$;

- у грудні 1941 р. разом із військовополоненими розстріляно 140 євреїв та 40 інших ув'язнених. У Новоолександрівці розстріляно 54 євреї. Цією каральною операцією керував особисто Г. Занднер ${ }^{50}$;

- у січні 1942 р. розстріляно 80 євреїв та 14 інших ув'язнених, арештовано близько 40 осіб;

- у лютому 1942 р. розстріляно близько 230 євреїв та 60 осіб з числа радянського і партійного активу, злочинців та ін ${ }^{51}$. Важливою деталлю $є$ те, що 16 лютого через кур'єра були отримані особливі вказівки з Києва про розстріл місцевої української інтелігенції за таким планом: арешти мали бути проведені безпосередньо перед розстрілом і необхідно було намагатись провести їх непомітно (наскільки це було можливим). Термін виконання наказу був встановлений не пізніше 20 лютого 1942 р. У додатку до наказу, отриманого Гансом Занднером, містилась вимога про негайне спалення документа після ознайомлення з його змістом. Не було необхідності повідомляти про виконання операції ні усно, ні письмово. Проте операція не була проведена з технічних причин: автомашини, окрім однієї, були несправні, частина співробітників СД виявилась у відпустці. Саме через це на виконання відповідного наказу, отриманого з Києва, до каральної операції була залучена зондеркоманда із охоронної поліції під керівництвом лейтенанта Шмідта, яка й розстріляла сімох українців-бандерівців і представників інтелігенції ${ }^{52}$;

- у березні-квітні 1942 р. розстріляно близько 80 євреїв із числа міських мешканців, близько 120 осіб із табору військовополонених та 60 інших ув'язнених ${ }^{53}$. Приблизно 29-30 квітня була проведена спеціальна каральна операція у психіатричній лікарні м. Херсона, де було розстріляно 200 хворих, головним чином євреїв, зокрема хворих

\footnotetext{
${ }^{48}$ Статистика та деталі знищення населення - власні свідчення Г. Занднера.

${ }_{49}$ Мова йде про концтабір для радянських військовополонених «Шталаг 364». Розташовувався в центральній частині Миколаєва, за Інгульським мостом.

50 ГДА СБУ, ф. 11, оп. 1, спр. 1043, т. 1, арк. 15.

51 ГДА СБУ, ф. 11, оп. 1, спр. 1043, т. 1, арк. 17.

52 ГДА СБУ, ф. 11, оп. 1, спр. 1043, т. 1, арк. 16.

53 ГДА СБУ, ф. 11, оп. 1, спр. 1043, т. 1, арк. 18.
}

на туберкульоз та подагру. Цією операцією керував безпосередньо штурмфюрер Рьоппер ${ }^{54}$.

У цілому за період з листопада 1941 до квітня 1942 р. поліцією безпеки та СД було розстріляно орієнтовно 1300 осіб, у тому числі близько 500 євреїв різної статі та віку. Крім того, близько 400 радянських громадян запроторені до в'язниці ${ }^{55}$.

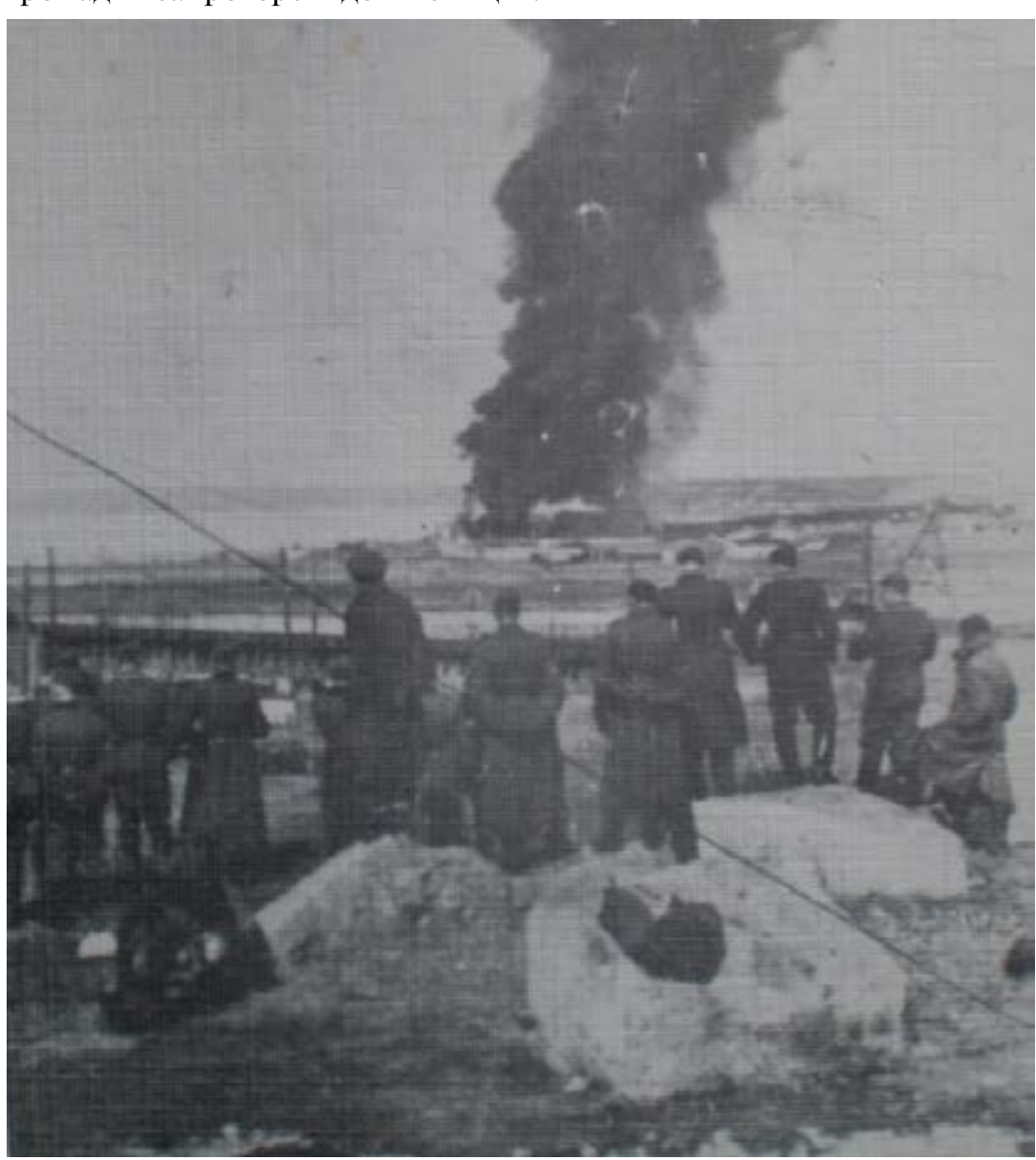

Результат диверсії радянських диверсантів на німецькому аеродромі. 10 березня 1942 p.56

\footnotetext{
54 ГДА СБУ, ф. 11, оп. 1, спр. 1043, т. 1, арк. 17.

55 ГДА СБУ, ф. 11, оп. 1, спр. 1043, т. 1, арк. 91.

${ }^{56}$ Державний архів Миколаївської області (далі - ДАМО), фотодокументи, оп. 1, од. зб. 6104.
} 
Для залякування місцевого населення практикувались і показові страти на шибениці в центрі Миколаєва. Такі акції відплати відбувались у результаті успішних диверсій радянського підпілля під керівництвом головного резидента радянської розвідки Віктора Лягіна (Корнєва), що реалізовувались з кінця 1941 р. Оскільки реальні виконавці не були знайдені, відомство Ганса Занднера брало заручників із місцевого населення під час масових облав у місті, а також частину арештованих із внутрішньої в'язниці поліції безпеки та СД (вул. Велика Морська). Для цієї мети в центрі міста на Базарній площі була встановлена стаціонарна шибениця ${ }^{57}$. Перша страта десятьох заручників відбулась 3 січня 1942 р. Друга страта інших десятьох заручників проведена 10 березня 1942 р. ${ }^{58}$ як акція відплати за вибух на території німецького аеродрому (за Інгульським мостом), здійснений радянським диверсантом О. Сидорчуком. Під час тієї диверсії на аеродромі згоріло 27 різних літаків, багато авіамоторів, 2 ангари, 35 тонн палива ${ }^{59}$.

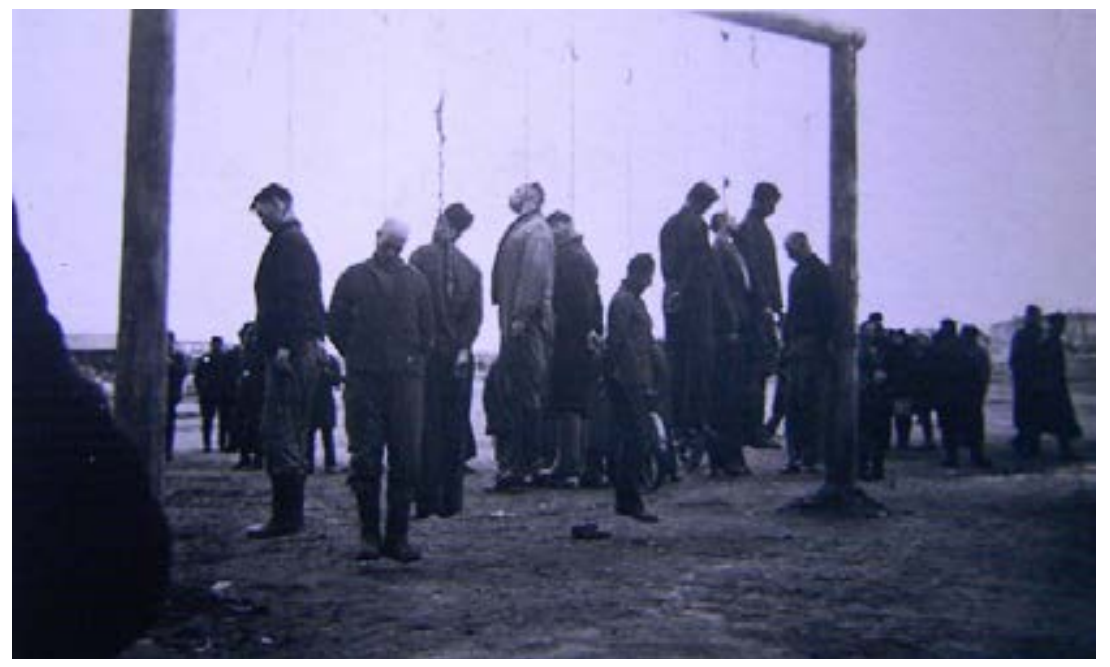

Страта заручників на Базарній площі в центрі Миколаєва. 10 березня 1942 p. .0

\footnotetext{
57 САЗ УСБУ в Миколаївській області, ф. 5, оп. 1, спр. 13204, т. 2, арк. 10 зв.

${ }_{58}$ САЗ УСБУ в Миколаївській області, ф. 5, оп. 1, спр. 13204, т. 2, арк. 248.

59 Євген Горбуров, «Підпільний та партизанських рух на території Миколаївщини в роки Великої Вітчизняної війни», у Миколаївщина в роки Великої Вітчизняної війни: 1941-1944рp. (До 60-річя визволення області від німецько-румунських окупантів) (Миколаїв: Квіт, 2004), 71.
}

${ }_{60}$ САЗ УСБУ в Миколаївській області, ф. 5, оп. 1, спр. 13262.
Екзекуція відбувалась у такий спосіб. У день страти всі вільні від чергування в СД вахмани, зокрема й Олександр Гроза, виїхали на Базарну площу і створили оточення, периметр якого був на відстані 20-25 м від шибениці. Незабаром до місця страти прибув шеф СД Г. Занднер на своїй легковій машині, а також ше одна легкова машина з офіцерами СД та одна крита вантажівка, у якій під охороною перекладачів СД привезли десять заручників, попередньо затриманих на базарі. У всіх приречених осіб були зв'язані руки. Стратою керував слідчий СД Шульц. Вантажівка із заручниками зупинилась під перекладиною шибениці, до якої вже були прикріплені мотузяні петлі. На борти машини була покладена дошка, на яку поставили всіх десятьох заручників. Приреченим людям одягли на шиї петлі, після чого машина від’їхала. Після страти всі трупи продовжували висіти близько доби ${ }^{61}$.

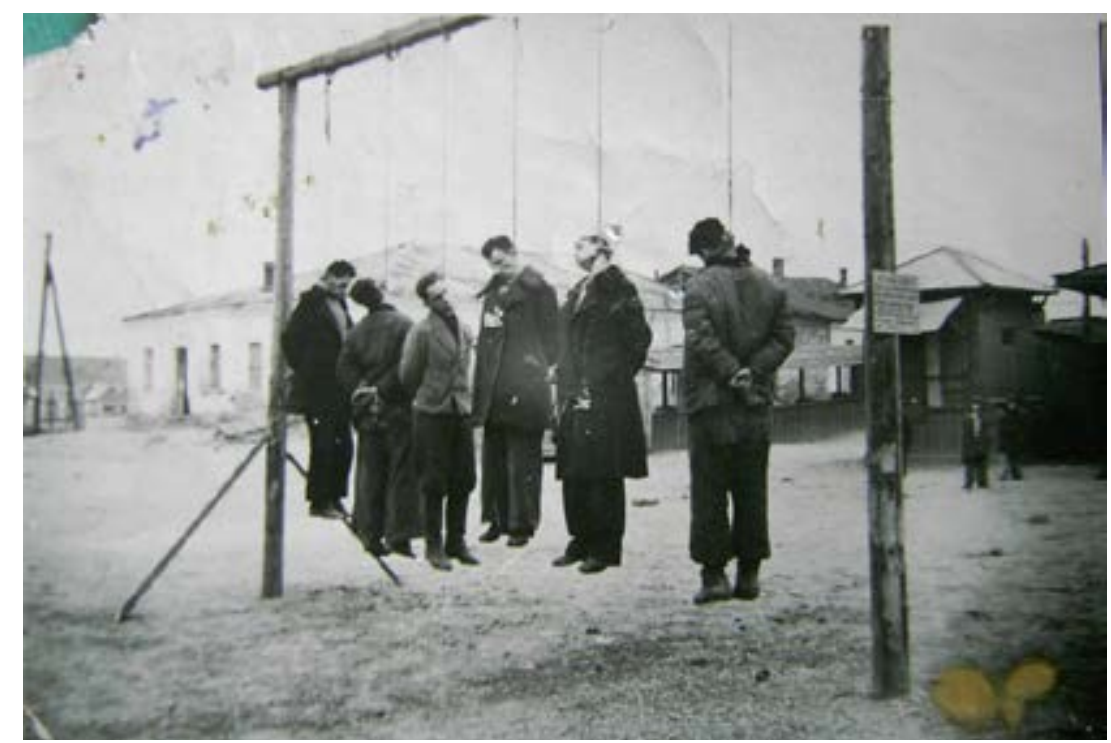

Страта арештованих на шибениці. Напис на звороті: «Виселица в Николаеве. Площадь вокзала около "складов" [нерозбірливо]”. Очевидно, йдеться про площу біля старого залізничного вокзалу. Дата невідома ${ }^{62}$.

\footnotetext{
${ }_{61}$ САЗ УСБУ в Миколаївській області, ф. 5, оп. 1, спр. 13204, т. 2, арк. 11-12.

62 САЗ УСБУ в Миколаївській області, ф. 5, оп. 1, спр. 13262.
} 
Оскільки Ганс Занднер був тимчасовим шефом поліції безпеки та СД, 20 березня 1942 р. в Миколаїв прибув новопризначений начальник поліції безпеки та СД штурмбанфюрер доктор Леопольд Шпанн. Заклад було перейменовано з «ЕК Ц-5» (Einsatzkommando C 5) поліції безпеки та СД в Управління поліції безпеки та СД. До цього Леопольд Шпанн обіймав посаду шефа гестапо в містах Лінц та Штеттін. При новому керівнику поліції безпеки та СД Ганс Занднер виконував обов'язки його заступника ${ }^{63}$ до 6 червня 1942 р., тобто до свого повернення в Німеччину ${ }^{64}$.

У цей час в Миколаєві також протягом короткого часу перебував штурмбанфюрер СС Вілке як головний експерт у справах СД. Але через три-чотири тижні він поїхав, оскільки був призваний у війська CC.

За березень-квітень 1942 р. штат Управління поліції безпеки та СД збільшився на 20 співробітників і становив загалом близько 40 осіб. 3 того часу заарештовані громадяни утримувались у міській в'язниці, начальником якої був обершарфюрер СС Карл Нольте ${ }^{65}$ (можливо, Нольде).

В Управлінні поліції безпеки та СД генеральної округи «Миколаїв» служили імперські німці, фольксдойче, росіяни та українці. Усі керівні посади обіймали лише імперські німці. Фольксдойче використовувались на посадах перекладачів (помічники слідчих), вахманів (шуцманів), водіїв, кухонних працівників. Українці та росіяни служили шуцманами, водіями ${ }^{66}$. У цілому основний штат СД нараховував близько 40 осіб ${ }^{67}$.

Зауважимо, що матеріали допитів колишнього перекладача СД Івана Бернгардта містять інформацію про те, що всі співробітники поліції безпеки та СД брали безпосередню участь в облавах, допитах, розстрілах, займались мародерством тощо ${ }^{68}$. Перекладачі СД не тільки перекладали доноси від громадян, інформаційні повідомлення від агентів, запитання та відповіді під час допитів, а й брали активну участь в арештах і розстрілах місцевих мешканців, катуваннях, виїздили на місця вбивств. Водночас перекладачі мали право самостійно

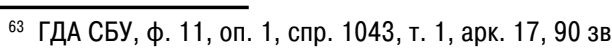

64 ГДА СБУ, ф. 11, оп. 1, спр. 1043, т. 1, арк. 20.

65 ГДА СБУ, ф. 11, оп. 1, спр. 1043, т. 1, арк. 19.

${ }^{66}$ САЗ УСБУ в Миколаївській області, ф. 5, оп. 1, спр. 13204, т. 2, арк. 217-218.

${ }^{67}$ ГДА СБУ, ф. 11, оп. 1, спр. 1043, т. 1, арк. 18.

${ }_{68}$ САЗ УСБУ в Миколаївській області, ф. 5, оп. 1, спр. 13204, т. 2, арк. 225-226. арештовувати підозрілих для окупаційної влади осіб ${ }^{69}$. Вахмани почергово охороняли головні будівлі СД, водили ув'язнених на роботу, на допити, конвоювали їх до центральної в'язниці СД, брали участь в облавах, охороняли місця показових страт біля шибениці чи місця, де розстріли відбувались приховано ${ }^{70}$.

\section{Структура та штат окружного управління поліції безпеки та СД}

На основі документів радянської контррозвідки, матеріалів допитів колишніх співробітників СД можна отримати доволі детальну інформацію про структуру і штат Управління поліції безпеки та СД генеральної округи «Миколаїв» у 1942-1944 рр. Штат, звісно, у різний час змінювався з тих чи інших причин, але в цілому картина зрозуміла.

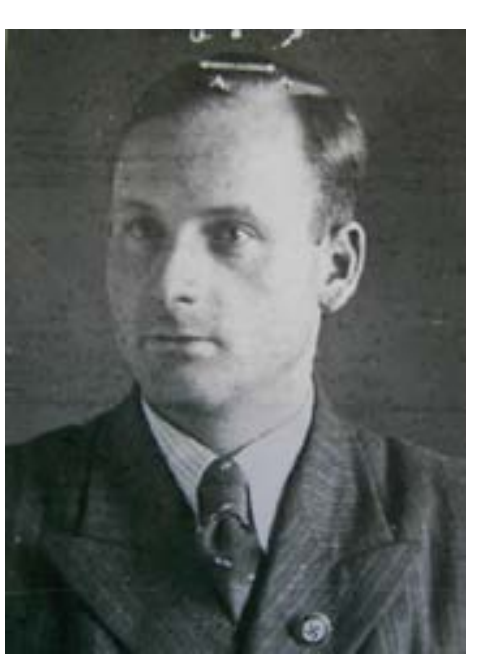

Управління поліції безпеки та СД, як відомо, з березня 1942 до березня 1944 р. очолювали штурмбанфюрер СС доктор Леопольд Шпанн (20 березня 1942 - серпень 1943 р.) та штурмбанфюрер СС Фрідріх Хегеншайд (серпень 1943 - березень 1944 р.) $)^{71}$. Їх заступниками почергово були оберштурмфюрер СС Ганс Занднер (нетривалий час), офіцер Кальбах ${ }^{72}$, начальник IV відділу унтерштурмфюрер СС Кокерольс ${ }^{73}$.

Штурмбанфюрер СС доктор Леопольд Шпанн. Світлина 1936 p. $^{74}$

Миколаївському окружному Управлінню поліції безпеки та СД підпорядковувались філії, що дислокувались у м. Херсоні, Кіровограді, Первомайську, Вознесенську, Цюрюпинську (Олешки), а на

\footnotetext{
${ }_{69}$ САЗ УСБУ в Миколаївській області, ф. 5, оп. 1, спр. 13204, т. 2, арк. 357.

70 САЗ УСБУ в Миколаївській області, ф. 5, оп. 1, спр. 13204, т. 2, арк. 43-44.

71 чуев, Спецслужбы Третьего Рейха, 71.

72 САЗ УСБУ в Миколаївській області, ф. 5, оп. 1, спр. 13204, т. 2, арк. 40 зв.

73 ГДА СБУ, ф. 11, оп. 1, спр. 1043, т. 1, арк. 2.

74 ГДА СБУ, ф. 11, оп. 1, спр. 1043, т. 11, арк. 1.
} 
початку 1944 р. також була підпорядкована Криворізька філія СДㄱ. Окрім цього, у населених пунктах працювали понад 100 штатних агентів, які створювали й свою мережу. Їх функції полягали у зборі необхідної інформації ${ }^{76}$.

Окружне Управління поліції безпеки та СД складалось із п'яти відділів:

І відділ (відділ «F»)

Начальник відділу - унтерштурмфюрер СС доктор Вайс, перекладачка - німкеня Амалія Гертер.

Відділ займався наданням перепусток цивільному населення для перетину німецько-румунського кордону по р. Південний Буг (тобто кордону Трансністрії). Крім того, на початку 1944 р. співробітники відділу займались оформленням перепусток цивільним особам, які евакуювались із Миколаєва.

ІІ відділ

Керівник - гаупштурмфюрер СС Ріш, його заступник - оберштурмфюрер СС Ресхофт. У цьому відділі розташовувалась реєстратура у складі трьох службовців. Відділ реєстрував усі агентурні справи, що надходили до СД, вів листування з іншими органами. Там збереглись усі архівні та слідчі справи.

До складу другого відділу входило також господарсько-фінансове відділення та бібліотека. Цей відділ зберігав списки співробітників СД, а також здійснював виплату заробітної платні. Там працювало 7-8 німців ${ }^{77}$ : завгосп Управління штурмшарфюрер СС Бено Мускаллє, касир - унтершарфюрер СС Зайферт, друкарки - Ціммерман, Ліндеман Альма. Відділення реєстратури очолював обершарфюрер СС Вінкельман. Перекладач - Олександр Фрізон ${ }^{78}$.

III відділ (відділ «N»)

Керівник відділу - штурмфюрер СС Сільверс, його заступник шарфюрер СС Зайц (можливо, Зейц $)^{79}$. Зайц був німцем із Румунії, раніше служив у поліції безпеки та СД м. Києва ${ }^{80}$. У відділі було два перекладачі, один із них - Оскар Баудер.

75 ГДА СБУ, ф. 11, оп. 1, спр. 1043, т. 1, арк. 2.

${ }^{76}$ САЗ УСБУ в Миколаївській області, ф. 5, оп. 1, спр. 13204, т. 2, арк. 136.

77 ГДА СБУ, ф. 11, оп. 1, спр. 1043, т. 1, арк. 2-3.

78 ГДА СБУ, ф. 11, оп. 1, спр. 1043, т. 1, арк. 37 зв.

79 ГДА СБУ, ф. 11, оп. 1, спр. 1043, т. 1, арк. 3.

${ }_{80}$ САЗ УСБУ в Миколаївській області, ф. 5, оп. 1, спр. 13204, т. 2, арк. 139-140.
III відділ був агентурно-оперативним. У ньому зосереджувалось все керівництво агентурною роботою: вербування агентів та обробка різних повідомлень. Агентуру приймав штурмфюрер СС Сільверс, його заступник чи перекладач. Усі агентурні повідомлення, що надходили, після відповідного оформлення передавались у IV відділ основний відділ поліції безпеки та СД.

У структурі III відділу було відділення інформації, яке займалось підготовкою доповідних записок про настрої населення в місті та області. Очолював цей підрозділ унтерштурмфюрер СС Меркле (родом iз Вюртемберга). Перекладачами служили Віктор Ельфімов, а потім - Віктор Треммель. Доповідні записки складались на основі агентурних повідомлень та особистих спостережень співробітників СД, зокрема перекладачів, які, з’ясовуючи настрої населення, відвідували кінотеатри, ресторани та інші громадські місця.

IV відділ (політичний)

Цей підрозділ був основним відділом поліції безпеки та СД, який керував всією слідчою та частково агентурною роботою. Його очолював унтерштурмфюрер СС Кокерольс, а посаду заступника обіймав штурмшарфюрер СС Рьоппер ${ }^{81}$.

IV відділ складався із двох підрозділів. Найбільшим був відділ IV C (очолював унтерштурмфюрер СС Кокерольс), співробітники якого займались виявленням комуністів, радянських розвідників, членів підпільних організацій та груп чи осіб, які проводили антинімецьку агітацію $^{82}$

Старшими слідчими цього відділу були штурмшарфюрери СС Альфред Рьоппер і Віллі Реллінг, які займались найбільш важливими справами ${ }^{83}$. Штатними слідчими - штурмшарфюрери СС Люнау, Треммер, Шуман, Хамахер, обершарфюрери СС Карл Кніттель, Гросс. Серед перекладачів-слідчих - Карл Ліндеман, Іван Бернгардт, Маркус Іммель, Флек, Гайтуф, Гінцман, Вінгертер. Друкарка відділу - Кеніг (родом з Німеччини) ${ }^{84}$. Крім того, відомо, що слідчий Інтвен - мешканець м. Штуттгарда, Шуман - мешканець м. Гамбурга, Люнау - мешканець м. Дюссельдорфа. Слідчий Хамахер прибув до Миколаєва на початку лютого 1944 р. з Нікопольського СД, яке він певний час очолював ${ }^{85}$.

\footnotetext{
81 ГДА СБУ, ф. 11, оп. 1, спр. 1043, т. 1, арк. 3.

82 САЗ УСБУ в Миколаївській області, ф. 5, оп. 1, спр. 13204, т. 2, арк. 220.

${ }^{83}$ САЗ УСБУ в Миколаївській області, ф. 5, оп. 1, спр. 13204, т. 2, арк. 40 зв.

84 ГДА СБУ, ф. 11, оп. 1, спр. 1043, т. 1, арк. 3.

${ }^{85}$ САЗ УСБУ в Миколаївській області, ф. 5, оп. 1, спр. 13204, т. 2, арк. 136-137.
} 
Відділ IV А займався спочатку пошуком євреїв, а пізніше - членів ОУН. Начальником відділу до осені 1942 р. був обершарфюрер Карл Ланге, а його помічником - шарфюрер Нольте. У 1943 р. слідчим у справах євреїв був штурмфюрер СС Штеффен.

Підвідділ ОУН був виокремлений у самостійний після 1943 р. ${ }^{86}$ Це відділення очолював гаупштурмфюрер СС Отт ${ }^{87}$.

Картотека - реєструвались усі арештовані СД. Відповідальним за картотеку був штурмшарфюрер СС Морісе. Перекладачами служили Брільц і Міхель, діловод - Людмила Флек.

Радіовідділ (самостійний) - підтримував зв'язок із філіями СД у Херсоні, Первомайську, Кіровограді та ін. У відділенні працювали обершарфюрер СС Штак, радисти - Мартін і Блеформ ${ }^{88}$.

V відділ (Кримінальна поліція)

Керівник - штурмшарфюрер СС Отто Рункель ${ }^{89}$, його заступники штурмшарфюрери СС Ібеляккер і Адельман. У їх підпорядкуванні був «російський» начальник Анатолій Мєшков. Основний напрям відділу - кримінальні справи, але в кінці 1943 р. в ньому було створено відділення на чолі з Шевченком, яке займалось політичними справами. Особовий склад цього відділу становили місцеві мешканці, незалежно від національності.

V відділ (Кріпо) складався із відділень:

1. Агентурно-оперативне відділення на чолі з Костянтином Бєлухою, який мав у підпорядкуванні штатних агентів. Вони ходили в цивільному одязі, здійснювали арешти, обшуки, брали участь у засідках та облавах на громадян. Крім того, кожен із них був резидентомвербувальником, мав на зв’язку своїх «шпіків». Усі агентурні повідомлення передавались К. Бєлусі, який планував подальші заходи.

2. Слідче відділення очолював старший слідчий Евген Олександрович Мєшалін. Співробітники: М. М. Постпєлов, Г. М. Вартєньєв, Чмирь, Музика, Казаков, Зорін (до прибуття в Миколаїв був начальником Кріппо в м. Маріуполі), Сохін, Шанов-Попов, Степанюк, Осталевич, Милорадов, Єнюхін, Крант.

Слідчий склад V відділу поділявся на дві частини: одні співробітники займались кримінальними справами на цивільних осіб ненімецької національності, інші - на місцевих німців.

${ }_{86}$ САЗ УСБУ в Миколаївській області, ф. 5, оп. 1, спр. 13204, т. 2, арк. 139

87 ГДА СБУ, ф. 11, оп. 1, спр. 1043, т. 1, арк. 4.

${ }_{88}$ ГДА СБУ, ф. 11, оп. 1, спр. 1043, т. 1, арк. 4-5.

89 ГДА СБУ, ф. 11, оп. 1, спр. 1043, т. 2, арк. 37.
Політичне відділення очолював слідчий Шевченко, який мав у підпорядкуванні двох штатних агентів Русинова і Васильєва. Шевченко через них керував агентурою, вів слідство у справах політичного характеру, що з'являлись на основі оперативних матеріалів V відділу.

V відділ управління поліції безпеки та СД розміщувався в окремому будинку на вул. Плеханівскій, 34, мав напис «Кримінальна поліція» ${ }^{90}$. Загалом у відділі було до десяти слідчих і до тридцяти штатних агентів ${ }^{91}$.

Комендантом Управління поліції безпеки та СД був штурмман СС Роммель ${ }^{92}$. Охорона будівель СД комплектувалась із місцевих німців (фольксдойче). Основні функції зводились до охорони будівель СД та заарештованих, які утримувались у внутрішній в’язниці СД (вул. Велика Морська). Начальником караулу був Михайло Якович Шерер, шуцманами - Олександр Гроза та ін ${ }^{93}$.

Центральна в'язниця поліції безпеки та СД перебувала безпосередньо в підпорядкуванні шефа СД, розташовувалась у Миколаєві за адресою вул. Лагерне поле, 5 (нині - слідчий ізолятор МВС). Усі затримані після завершення «слідства» направлялись до в'язниці з наступним етапуванням до Німеччини. Комендантом центральної в’язниці поліції безпеки та СД з березня 1942 р. був обершарфюрер СС Карл Нольте ${ }^{94}$. Із серпня 1942 до січня 1943 р. на посаді коменданта центральної в'язниці СД служив Євгеній Мартін (фольксдойче) ${ }^{95}$, а після нього - Іван Шехтерлє (фольксдойче). За нового коменданта в'язниці Івана Шехтерлє Євгеній Мартін виконував обов'язки начальника караулу до червня 1943 р., а згодом служив простим охоронцем в'язниці до березня 1944 р. ${ }^{96}$

Миколаївське окружне Управління поліції безпеки та СД мало у своєму підпорядкуванні окремий концентраційний табір для цивільних осіб. Табір дислокувався на відстані 35 км від Миколаєва та за 2,5 км від залізничної стації Грейгове ${ }^{97}$ (у селі Водокачка). Комендантом табору був німець Нольде (так у документі), його

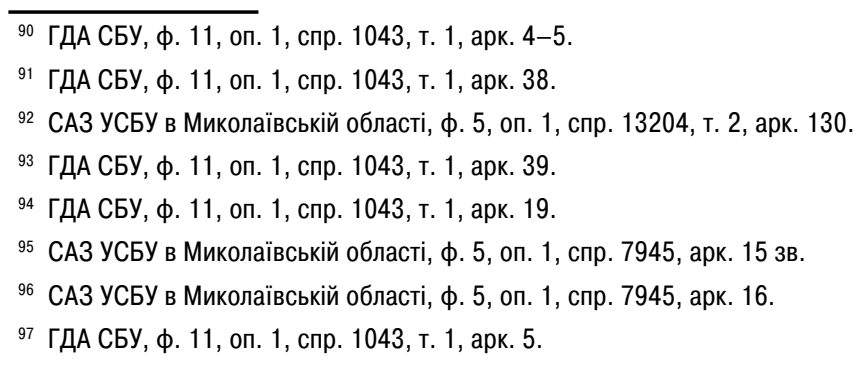


заступником - німець Фаут ${ }^{98}$. Імовірно, мова йде про обершарфюрера СС Карла Нольте, який був першим начальником центральної в'язниці поліції безпеки та СД у Миколаєві ${ }^{99}$.

Штатними перекладачами при Управлінні поліції безпеки та СД генеральної округи «Миколаїв» служили місцеві німці (фольксдойче): Едуард Карі, Свгеній Гопфауф, Віктор Треммель ${ }^{100}$, Маркус Іммель, Іван Бернгардт (див. фото нижче) ${ }^{101}$, Рудольф Ціммерман, Мартін Вінкертер, Рафаїл Бірк (колишній директор школи у с. Гольбштадт Варварівського району, вбитий 4 грудня 1942 р. під час спроби

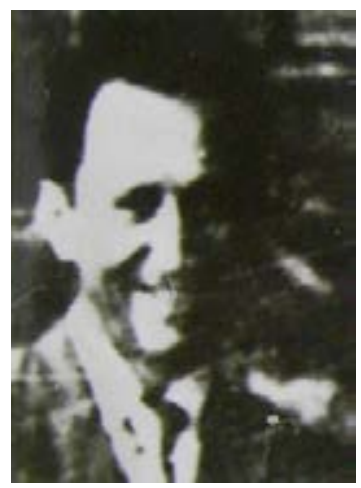

Едуард Карі

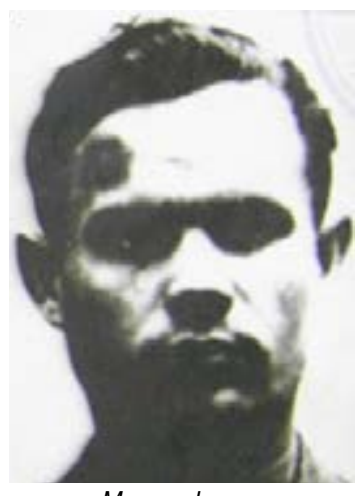

Маркус Іммель

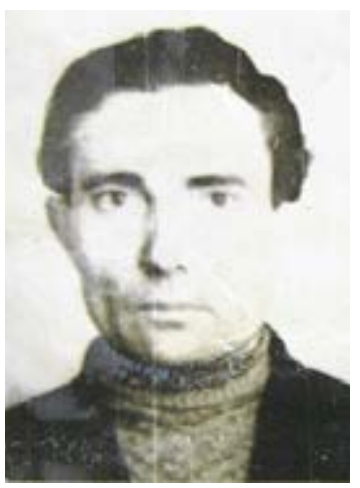

Євгеній Гопфауф

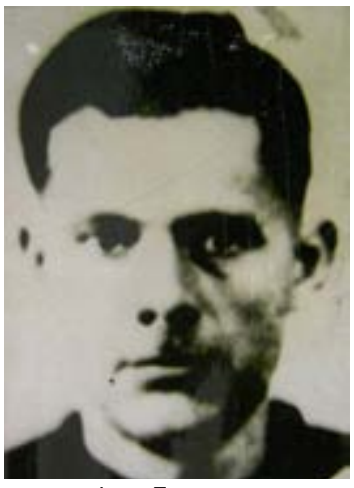

Іван Бернгардт

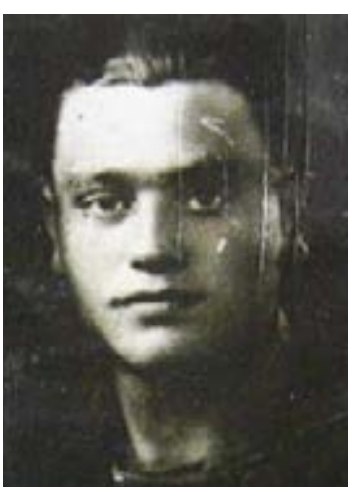

Віктор Треммель

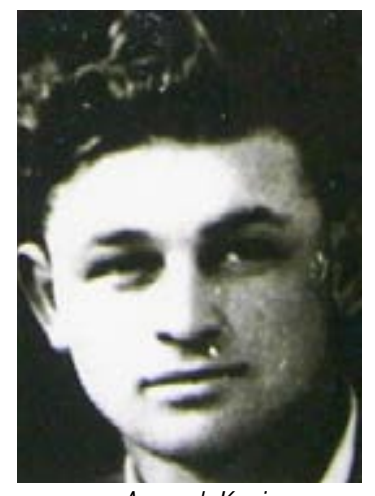

Адольф Карі
${ }_{98}$ САЗ УСБУ в Миколаївській області, ф. 5, оп. 1, спр. 13204, т. 2, арк. 80.

99 ГДА СБУ, ф. 11, оп. 1, спр. 1043, т. 1, арк. 19.

100 Віктор Треммель брав участь у допитах (вочевидь, і у катуваннях) головного резидента радянської розвідки у Миколаєві Віктора Лягіна (Корнєва).

101 САЗ УСБУ в Миколаївській області, ф. 5, оп. 1, спр. 13204, т. 2, арк. 445. затримання радянського підпільника П. Комкова) ${ }^{102}$, Адольф Карі, Маркус Флек ${ }^{103}$, Віктор Гінцман, Карл Ліндеман ${ }^{104}$ та ін.

Вахманами, водіями та іншими співробітниками поліції безпеки та СД у різний час служили Евгеній Ліпперт, Лео Таубергер, Микола Сиволоб, Адольф Лещинський, Роман Міллер, Віктор Дік, Міхель Антон, Яков Вайнерт, Антон Брільц, Антон Брільц, Адольф Карі, Мартін Вінгертер, Іван Гопфауф, Федір Бенкендорф, Нікодим Штеклер, Віктор Рейнбольд, Михайло Горячев, Альфонс Мартін, Едуард Іммель, Йосиф Вебер, Нікодим Лещинський, Рохус Фрізон, Август Меклер ${ }^{105}$ та ін.

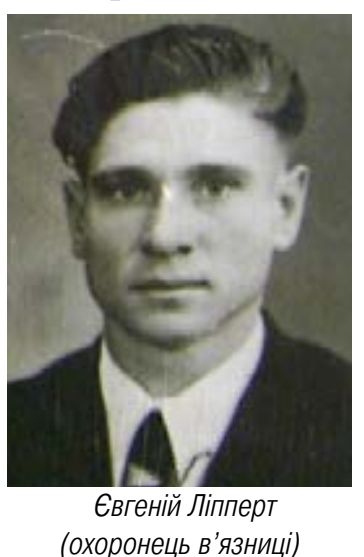

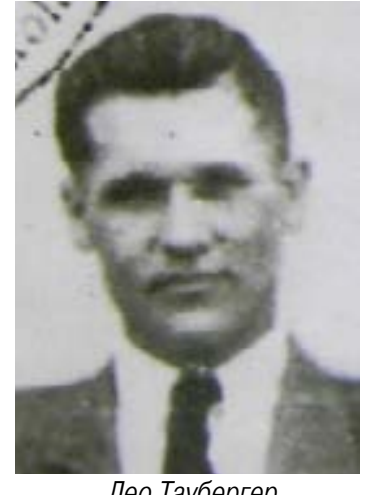

Лео Таубергер

(охоронець в'язниці)

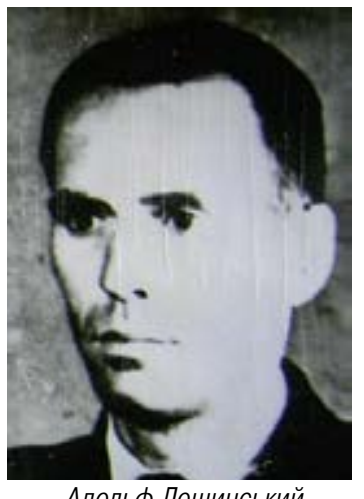

Адольф Лещинський (водій СД)

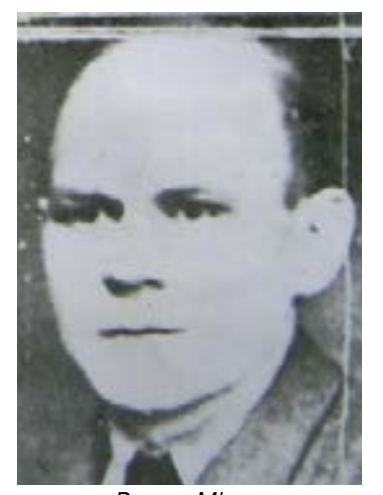

Роман Міллер

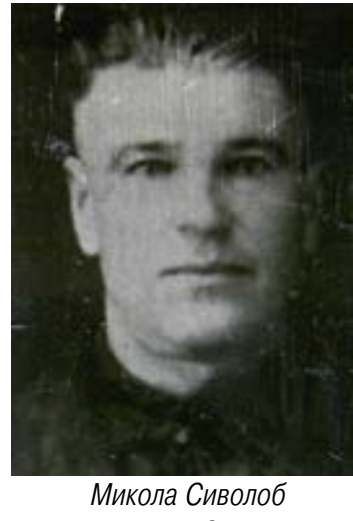

(водій СД)

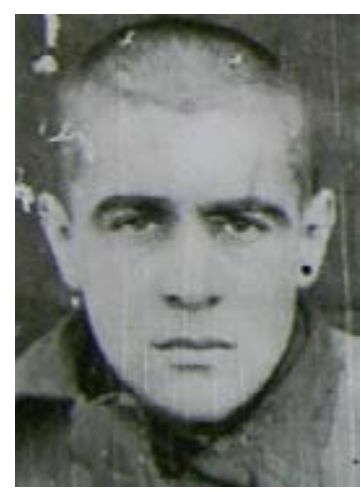

Віктор Дік
102 САЗ УСБУ в Миколаївській області, ф. 5, оп. 1, спр. 13204, т. 2, арк. 42.

103 САЗ УСБУ в Миколаївській області, ф. 5, оп. 1, спр. 13204, т. 3, арк. 321 зв., 322.

104 САЗ УСБУ в Миколаївській області, ф. 5, оп. 1, спр. 13204, т. 2, арк. 477-478.

${ }_{105}$ САЗ УСБУ в Миколаївській області, ф. 5, оп. 1, спр. 13204, т. 3, арк. 5, 8, 30, 33. 

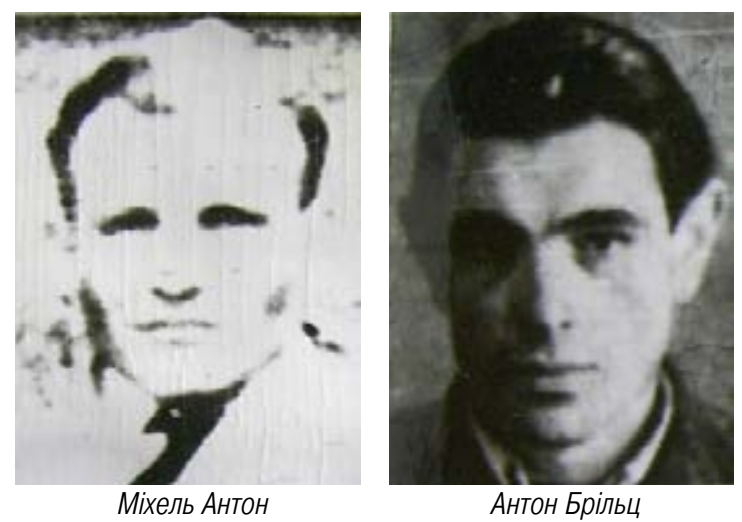

Антон Брільц

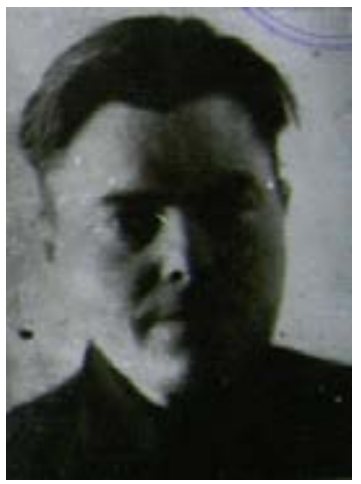

Антон Брільц

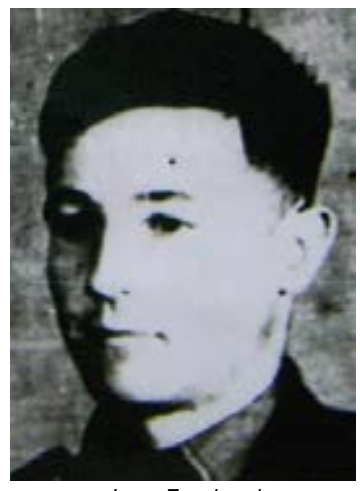

Іван Гопфауф

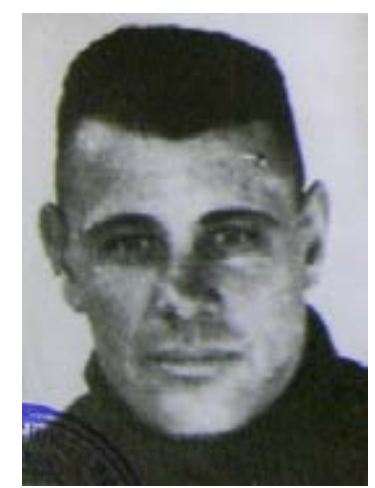

Адольф Карі

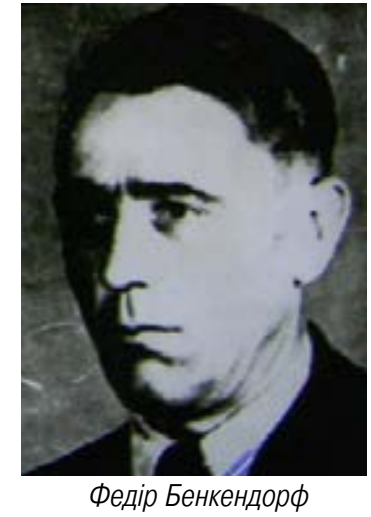

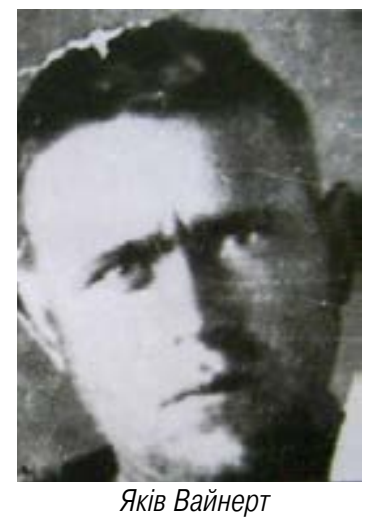

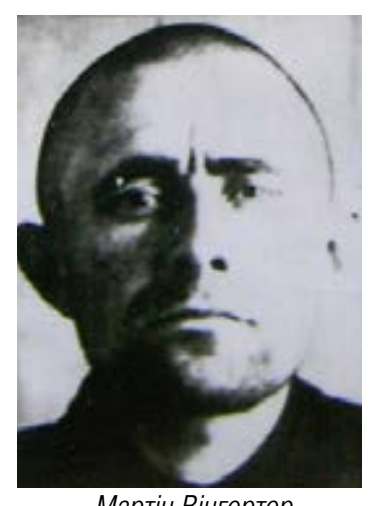

Мартін Вінгертер

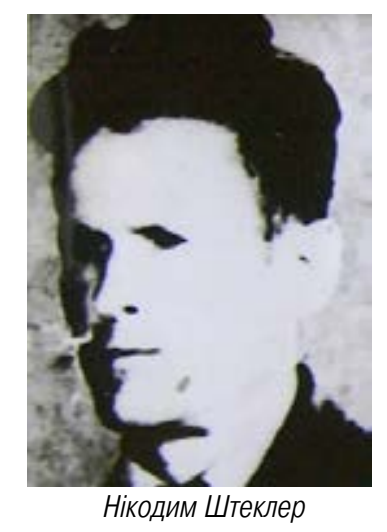

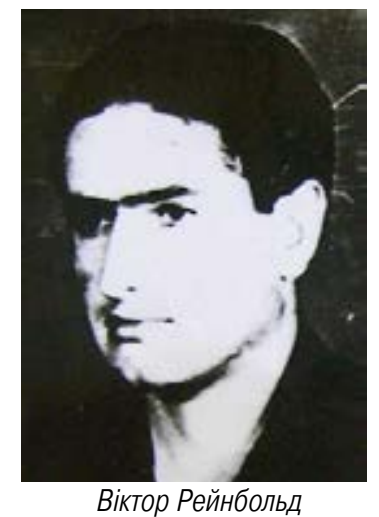
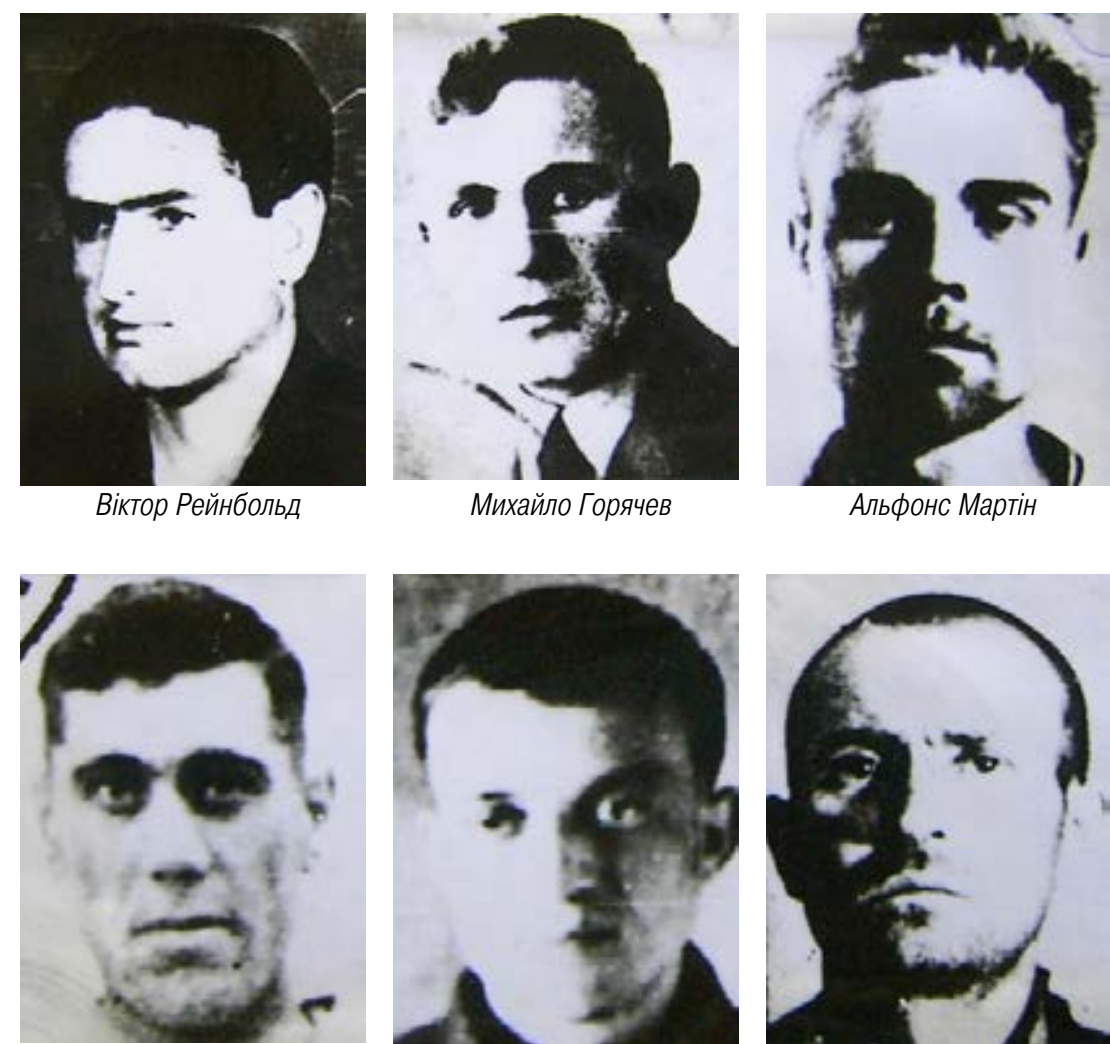

Едуард Іммель

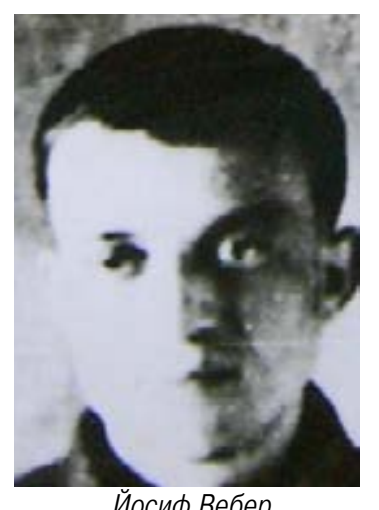

Йосиф Вебер

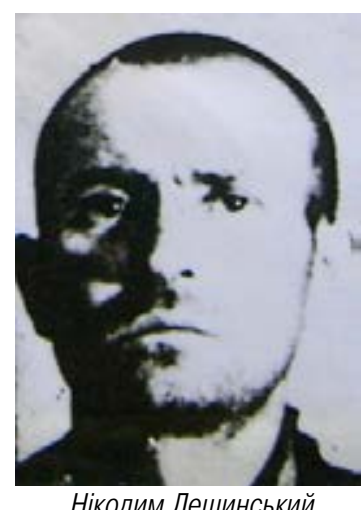

Нікодим Лещинський

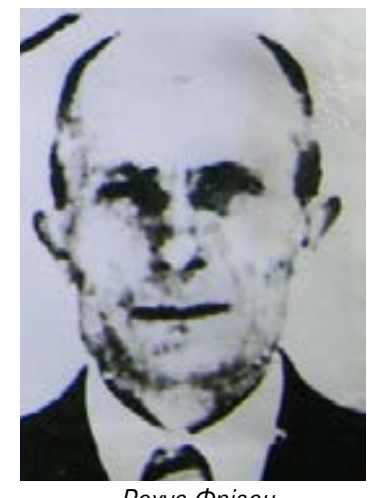

Рохус Фрізон
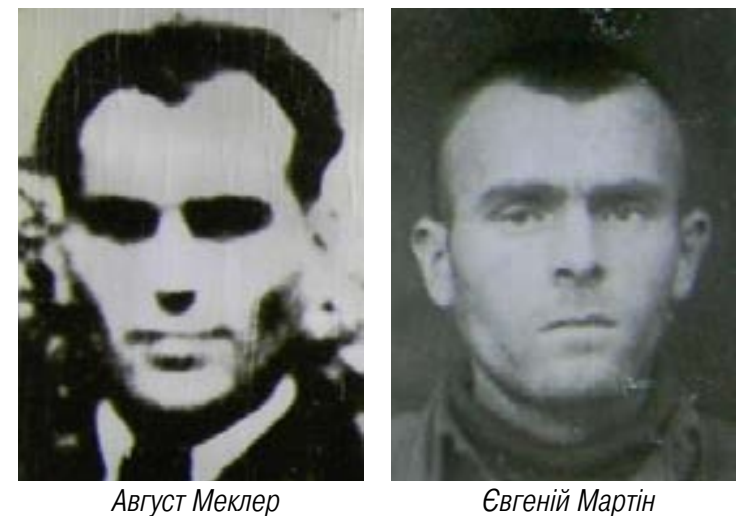

Євгеній Мартін (комендант в'язниці СД) 


\section{Способи отримання оперативної інформації: вербування агентів} і жорстокі допити арештованих

Основні зусилля співробітників поліції безпеки та СД (у взаємодії з Абверштеллє Півдня України) спрямовувались на виявлення та знищення будь-яких осередків організованого спротиву місцевого населення. Відомо, що під час окупації Миколаївщини в 1941-1944 pp. місцеве підпілля було представлено радянським напрямком (партійне, армійське, чекістське підпілля), що об'єднались в 1942 р. в «Миколаївський центр» під керівництвом В. Лягіна) та націоналістичним (ОУН-б, ОУН-м). Хоч радянське підпілля і здійснило ряд значних диверсій у 1941-1942 рр., але його організаційне ядро було швидко розкрите та знищене німецькими контррозвідувальними органами протягом перших півтора років окупації. На думку автора, основні причини провалу - це розгалужена агентурна мережа німецьких контррозвідувальних органів з числа колаборантів (в області нараховувалось близько 1200 фольксдойче, 1500 колишніх репресованих у 1920-1930-х рр. та ін.), зрада, зізнання підпільників у результаті катувань, шантажу, порушення конспірації, а в окремих випадках - непрофесіоналізм та загальна паніка під час організації підпілля ще на початковому етапі його підготовки в 1941 p.

Питання про розширення кількості інформаторів та агентів стояло дуже гостро. Ганс Занднер особисто давав вказівки проводити активне вербування агентів (до 5-6 осіб на тиждень), бажаючи створити відносно потужну агентурну мережу. Вербування здійснювалось різними методами. Агент з'являвся за власним бажанням до відповідного закладу і повідомляв інформацію. Після повторного відвідування він отримував грошову оплату чи винагороду іншого характеру (одяг, продукти харчування). Потім таку людину перевіряли, з'ясовуючи профпридатність, зв'язки, місце роботи та причини, що спонукали iii з'явитись до СД. Створивши такій особі кращі матеріальні умови чи можливість працювати за спеціальністю, їй повідомляли про обов’язок співпраці з органами СД. Осіб, які підлягали покаранню, вербували шляхом їх звільнення з-під арешту. Наприклад, деяких засуджених до смертної кари не розстрілювали ${ }^{106}$, а використовували після перевірки як «шпіків».

Агентурною роботою в Управлінні поліції безпеки та СД займались III, IV, V відділи, які самостійно вербували інформаторів. Через необхідність мати агентів на якомусь підприємстві слідчий СД виїздив туди і разом з його шефом обирав кандидатури. У таких ${ }_{106}$ ГДА СБУ, ф. 11, оп. 1, спр. 1043, т. 1, арк. 14. випадках ${ }^{107}$ відповідних людей для вербування добирали переважно з осіб, які постраждали від діяльності комуністичної влади: репресованих, розкуркулених і загалом антирадянськи налаштованих місцевих мешканців.

Відповідних осіб через шефа підприємства згодом викликали в III відділ поліції безпеки та СД, де їх вербування проводили співробітники цього відділу, зокрема й перекладачі. Крім того, для вербування використовувались громадяни, які за власною ініціативою приносили до СД доноси про ті чи інші антинімецькі прояви.

Також агентуру набирали із середовища учасників підпільних радянських організацій і членів ОУН, тобто осіб, заарештованих за приналежність до цих організацій. Цінність агентури визначалась важливістю наданої інформації. Вербуванню підлягали господарі ресторанів, буфетів та інших громадських закладів.

Окремий важливий напрям полягав у вербуванні колишніх військовослужбовців Радянської армії. Така агентура вважалась найбільш цінною і отримувала відповідальні завдання. Агенти ніде не працювали, існували за рахунок Управління поліції безпеки та СД, від якого мали грошову винагороду від 75 до 80 марок на місяць та продукти харчування. Таку агентуру забезпечували від СД біржевими картками і довідками, де зазначалось, що вони є співробітниками СД.

Агентура на підприємствах і виробництві отримувала завдання вивчати настрої населення серед робітників, виявляти партійнорадянський актив, який саботував заходи німців, а також тих, хто підозрювався у диверсіях та ін.

Агентуру із середовища заарештованих осіб добирали слідчі, використовували її для ефективнішої розробки ув'язнених. Траплялись випадки, коли таких агентів після використання з тих чи інших причин звільняли із СД і передавали для подальшого використання в 3-й (агентурний відділ) ${ }^{108}$.

Як не парадоксально, але агентурна мережа була краще налагоджена поліцією безпеки та СД, а не резидентами Абверштеллє, оскільки слідчим СД вдалось впровадити своїх агентів безпосередньо в підпільні організації ${ }^{109}$. Одним із методів провокації для виявлення радянських підпільників СД практикувало впровадження в патріотичні організації своїх співробітників (фольксдойче-перекладачів) під виглядом учасників підпілля. Це робилось за допомогою арештованих

107 ГДА СБУ, ф. 11, оп. 1, спр. 1043, т. 1, арк. 38.

108 ГДА СБУ, Ф. 11, оп. 1, спр. 1043, т. 1, арк. 38 зв.

109 САЗ УСБУ в Миколаївській області, ф. 5, оп. 1, спр. 13204, т. 2, арк. 181. 
громадян, які зізнались у належності до тих чи інших нелегальних організацій. Такі арештовані особи діяли в парі з перекладачами СД і разом з ними відвідували квартири людей, які мали зв'язок із місцевим підпіллям ${ }^{110}$.

Варто також зазначити, що значну кількість інформації про членів руху місцевого опору слідчі поліції безпеки та СД добували в результаті різних методів тортур, що застосувались до арештованих громадян. Багато ув’язнених не витримували катування в застінках СД, тому видавали знайомих підпільників. Колишній радянський підпільник Антон Криворучко (Новоодеський район) свідчив про деякі види відомих йому тортур. Зокрема, арештованого (незалежно від статі) роздягали і клали животом на круглий стілець, били батогом з металевим наконечником, гумовим шлангом, клали пальці рук у дверний отвір і ламали їх, здираючи шкіру з кісток, заганяли голки під нігті ${ }^{111}$. Вищезгаданий колишній вахман СД Олександр Гроза свідчив, що спеціальної кімнати для катування в СД не було. Усі допити проводились у шести кабінетах слідчих (див. вище розташовані фото та схему приміщень СД). Більшість арештованих повертались закривавленими, інколи їх непритомними витягували із цих кабінетів. Багато арештованих осіб після допитів повертались не тільки побиті, а й забруднені у власних екскрементах, бо не витримували тортур. Тоді після допитів у «робочі» кабінети направлялись для прибирання приміщення жінки, яких утримували під арештом. Найбільшими звірствами відзначались місцеві німці-перекладачі (фольксдойче): Едуард Карі, Маркус Іммель, Іван Бенгардт ${ }^{112}$.

\section{Деякі деталі процесу переслідувань, арештів та етнічних страт}

Частині місцевих євреїв вдалось уникнути розстрілу восени 1941 р. 3 різних причин. Наприклад, 20 лікарів-євреїв та 22 членів їх родин ${ }^{113}$ у період масових розстрілів залишили живими як цінних медичних спеціалістів. Вони продовжували працювати на окупантів, мешкали в себе вдома, але всі стояли на суворому обліку в поліції безпеки та СД. За наказом керівництва поліції безпеки та СД на початку квітня 1942 р. всі ці люди була заарештовані й зібрані в камерах внутрішньої в'язниці СД (вул. Велика Морська), де перебували недовго ${ }^{114}$.

110 САЗ УСБУ в Миколаївській області, ф. 5, оп. 1, спр. 13204, т. 2, арк. 327.

111 САЗ УСБУ в Миколаївській області, ф. 5, оп. 1, спр. 13204, т. 2, арк. 4 зв.

112 САЗ УСБУ в Миколаївській області, ф. 5, оп. 1, спр. 13204, т. 2, арк. 51-52.

${ }_{113}$ САЗ УСБУ в Миколаївській області, ф. 5, оп. 1, спр. 13262, арк. 182.

114 САЗ УСБУ в Миколаївській області, ф. 5, оп. 1, спр. 13204, т. 2, арк. 17-18.
Багатьох заарештованих забирали просто з ліжка. Серед затриманих був голова медичної спілки м. Миколаєва, лектор Інституту удосконалення лікарів, відомий терапевт 3.Р. Барг ${ }^{115}$, лікарі Самсов, А. Л. Коган, Скляр та ін.

Страта цих відомих людей відбулася 2 квітня 1942 р. ${ }^{116}$ Усіх лікарів і членів їх родин посадили в одну велику вкриту брезентом вантажівку. Євреїв відвезли до стіни концтабору для радянських військовополонених «Шталаг 364», де їх розстріляли у ямі, яка спеціально для цього була вирита радянськими військовополоненими. На місці розстрілу перебувало багато перекладачів СД на чолі з Г. Занднером, який особисто керував процесом знищення. За свідченнями Олександра Грози (конвоював цих людей, охороняв місце страти), на місці розстрілу вахмани (шуцмани) стояли в оточенні на відстані 10-15 м від ями, у якій відбувався розстріл. Машина зупинилась біля ями, яка мала глибину до 3 м, а ширину - 5 м. У яму вели приступки. Євреїв змушували роздягатись догола, а речі залишати у вантажівці. Після цього діти, люди похилого віку, жінки з маленькими дітьми спускались по одному в яму. У ямі перебував озброєний автоматник, один слідчий чи перекладач, який, стоячи у кутку ями, стріляв у потилицю кожному, хто спускався до ями. Перед пострілом людей змушували лягати обличчям долілиць. Дітей розстрілювали також, як і дорослих - по одному. Одна молода жінка спустилась до ями з немовлям на руках. За командою ката лягла обличчям донизу на трупи вже вбитих людей і прикрила дитину своїм тілом. Автоматник спочатку вбив жінку пострілом у потилицю, перевернув їі тіло, під яким лежало ще живе немовля, потім застрелив і його. Перед стратою люди просили помилувати їх, плакали, кричали, але ніхто на їх прохання не звертав уваги. Після розстрілу всі співробітники СД забрали із собою майно вбитих. Одяг та інші речі були продезинфіковані. Кращі речі забирали собі співробітники СД, а потім обмінювали на продукти харчування. Гірші речі забирали для своїх потреб вахмани ${ }^{117}$.

Співробітники поліції безпеки та СД активно проводили роботу з виявлення залишків змішаних українсько-єврейських, російськоєврейських родин, які переховувались на території міста та регіону. Якщо єврейкою була мати, то арешту і подальшому знищенню підлягала вона та їі діти. Коли євреєм був батько родини, то розстрілювали його і дітей. Інших членів родини (відповідно чоловіка чи дружину)

115 САЗ УСБУ в Миколаївській області, ф. 5, оп. 1, спр. 13262, арк. 22.

${ }^{116}$ САЗ УСБУ в Миколаївській області, $ф .5$, оп. 1, спр. 13262, арк. 32-33.

117 САЗ УСБУ в Миколаївській області, ф. 5, оп. 1, спр. 13204, т. 2, арк. 18-21. 
за національністю українців чи росіян або заарештовували на певний час за переховування євреїв, а пізніше відпускали чи відправляли із в'язниці СД у нацистські табори на території Німеччини для подальшого відбуття покарання. Наприклад, Валентина Касаурова була одружена з Ароном Ганапольським, якого розстріляли в перші дні окупації Миколаївської області в 1941 р. Після такого випадку вона більше не могла залишатись у своєї матері, що мешкала на вул. Велика Морська, 9, оскільки весь двір знав, що у неї двоє дітей від чоловікаєврея. Валентина переїхала на вул. Глазенапівську, 28 (сучасна вул. Декабристів) та переховувалась там з дітьми. Із січня 1942 р. жила (як з чоловіком) із Миколою Авраменком. Він до травня 1942 р. працював у кримінальній поліції (Кріпо), а згодом був заарештований за отриманий хабар. 19 листопада 1943 р. була заарештована й Валентина Касаурова, а дітей - розстріляли. У центральній в'язниці СД вона перебувала до березня 1944 р., а згодом була відправлена в концтабір у м. Новий Брандербург. Там працювала на будівництві авіазаводу до 1945 р. ${ }^{118}$ Автор з'ясував, що в березні-квітні 1943 р. у в'язниці СД утримувалось в одній камері понад 30 чоловіків, більшість 3 яких були затримані за те, що їхні дружини були єврейками. Серед них був і Василь Наваленко. Поки він та інші перебували у в'язниці, їх дружин та дітей розстріляли. Після завершення розстрілів членів їх родин, чоловіків відпустили додому ${ }^{119}$.

Про атмосферу терору та доносів проти єврейського населення може свідчити і такий випадок. У кінці 1942 - на початку 1943 р. в Миколаївське управління СД прийшла дівчина-єврейка віком близько 22-23 років. Її вени на руках були перерізані. Вона повідомила, що довго переховувалась від розстрілів, але вже не має ні сил, ні можливості переховуватись, тому вона порізала собі вени та вирішила з'явитись до СД. Дівчину ув'язнили в камері, де вона перебувала декілька днів. Коли настав черговий день розстрілів, іiі стратили за Інгульським мостом разом з іншими приреченими ${ }^{120}$.

Поголовному знищенню також підлягало й ромське населення. За допомогою вивчення протоколів допитів перекладача СД Івана Бернгардта (був присутнім на місці страти) вдалось з'ясувати, принаймні, деякі деталі одного масового розстрілу ромів. Восени 1942 р. близько 100 осіб (діти, жінки, літні люди) утримувались у центральній в'язниці СД (вул. Лагерне поле, 5) у корпусі, розташованому ліворуч

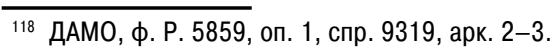

119 САЗ УСБУ в Миколаївській області, ф. 5, оп. 1, спр. 13204, т. 6, арк. 287.

120 САЗ УСБУ в Миколаївській області, ф. 5, оп. 1, спр. 13204, т. 2, арк. 22-23. від центральних воріт в'язниці. У дворі в'язниці ромів посадили у три вантажівки та відвезли до стін концтабору «Шталаг 364». Стратою цих людей керував начальник відділу 4 А обершарфюрер СС Карл Ланге. Під час розстрілу був присутнім штурмшарфюрер СС Альфред Рьоппер, перекладачі Іван Бернгард та Брільц, не менш як 50 шуцманів. Усіх вбивали по черзі одиночними пострілами в потилицю у ямі, що була завчасно підготовлена для цієї мети. Малолітніх дітей вбивали разом з їхніми матерями. Серед приречених була вагітна жінка середніх років. Її поклали обличчям додолу, вистрелили в потилицю, а потім перевернули та вистрелили в живіт. Поміж ромських жінок була дівчина віком близько 18 років, яка за зовнішніми ознаками не була схожа на циганку. Перекладач СД Іван Бернгардт запитав у Карла Ланге: «Чому розстрілюють цю дівчину, вона ж не схожа на циганку?» Той відповів: «Вона - циганка! Навіть якщо це не так, то іiі все одно розстріляють, оскільки вона жила разом з циганами». Цих людей розстрілював водій СД Віллі Вільгельм і шарфюрер Нольте 21 (імовірно, мова йде про шарфюрера Карла Нольте).

\section{Приховування слідів злочинів поліції безпеки та СД}

У грудні 1943 р. при Управлінні поліції безпеки та СД була створена спеціальна «зондеркоманда», яка діяла до березня 1944 р. Команда складалась з офіцера, двох-трьох солдатів СС, близько п’ятнадцяти вахманів СД. Команда займалась знищенням слідів раніше здійснених злочинів поліції безпеки та СД на території генеральної округи «Миколаїв», а також масовими розстрілами арештованих громадян, які на той час утримувались у в'язниці СД ${ }^{122}$. Крім того, окремі члени команди конвоювали деяких бранців центральної в'язниці СД у концтабори Німеччини ${ }^{123}$.

Усіх хворих на тиф та венеричні хвороби розстрілювали без роздумів за в’язницею СД у протитанкових ровах. Знищення слідів злочинів відбувалось у такий спосіб: у місцях масових розстрілів трупи відкопували п’ять відібраних бранців в’язниці СД. Викопані рештки тіл обливали відпрацьованим дизпаливом і підпалювали. Шуцмани стояли в оточенні місця спалення тіл на відстані 200 м, щоб не допустити сторонніх свідків. Таку «роботу» у грудні 1943 р. проводили на старому Єврейському кладовищі в Миколаєві, а в січні

121 САЗ УСБУ в Миколаївській області, ф. 5, оп. 1, спр. 13204, т. 2, арк. 230-233.

122 САЗ УСБУ в Миколаївській області, ф. 5, оп. 1, спр. 13204, т. 2, арк. 172-175.

${ }^{123}$ ГДА СБУ, ф. 11, оп. 1, спр. 1043, т. 1, ч. IV, арк. 49. 
1944 - у Первомайському, Вознесенському та інших районах ${ }^{124}$. Наприклад, один з учасників цієї спецгрупи Іван Штаудінгер свідчив, що 26 і 27 грудня 1943 р. весь склад «зондеркоманди» залучався для знищення слідів масових розстрілів на Єврейському кладовищі. Для виконання брудної роботи було привезено десять радянських громадян (бранців в'язниці СД), які безпосередньо відкопували трупи та спалювали їх горючою сумішшю. Була розкопана яма довжиною близько 10 м, у якій нараховувалось не менш як 400 трупів. Після виконаної роботи за наказом начальника «зондеркоманди» цих в’язнів розстріляли з автоматів Міллєр і Майєр ${ }^{125}$.

«Зондеркоманду» очолював гауптштурмфюрер СС Лезер (у Миколаїв приїхав з Німеччини). Особовий склад цієї спецгрупи складався 3 таких осіб:

1. Ротенфюрер СС Міллєр - заступник начальника «зондеркоманди» (у Миколаїв приїхав з Німеччини);

2. Штурмбанфюрер $\mathrm{CC}^{126}$ Майєр - був другим заступником начальника «зондеркоманди» (у Миколаїв приїхав з Німеччини);

3. Міхель Зайферт - рядовий солдат (фольксдойче, уродженець с. Ландау Миколаївської області);

4. Петро Брітнер - рядовий солдат (фольксдойче, уродженець Варварівського району Миколаївської області);

5. Антон Флек - рядовий солдат (фольксдойче, мешканець Миколаєва);

6. Йосиф Дінюс - рядовий солдат (фольксдойче, уродженець с. Зульц Варварівського району Миколаївської області);

7. Йосиф Меклер - рядовий солдат (фольксдойче, мешкав у с. Шенфельд Варварівського району Миколаївської області);

8. Олександр Гінцман - рядовий солдат (фольксдойче, мешкав у Миколаєві);

9. Нікодим Шваб - рядовий солдат (фольксдойче, мешкав у Миколаєві);

10. Карі - рядовий солдат (ім'я невідомо, фольксдойче, мешкав у с. Петрівці Варварівського району Миколаївської області);

11. Карі - рядовий солдат (ім'я невідомо, фольксдойче, мешкав у с. Каріфутер Варварівського району Миколаївської області);

12. Баштьян (Пашан) Вебер - рядовий солдат (фольксдойче, мешкав у Миколаєві);

124 САЗ УСБУ в Миколаївській області, $\phi .5$, оп. 1, спр. 13204, т. 2, арк. 172-175.

125 ГДА СБУ, ф. 11, оп. 1, спр. 1043, т. 1, ч. IV, арк. 49-50.

${ }^{126}$ Так у документі. Можливо, правильно - штурмфюрер СС.
13. Леопольд Вебер - рядовий солдат (фольксдойче, мешкав у Миколаєві);

14. Опфау (Гопфау) - рядовий солдат (ім'я невідомо, фольксдойче, мешкав у Миколаєві);

15. Антон - рядовий солдат (ім'я невідомо, фольксдойче, мешкав у с. Петрівці Варварівського району Миколаївської області);

16. Іван Штаудінгер - рядовий солдат (фольскдойче, мешкав у с. Зульц Варварівського району Миколаївської області) ${ }^{127}$.

\section{Евакуація штату поліції безпеки та СД і деякі післявоєнні долі злочинців}

Усі співробітники поліції безпеки та СД евакуювались з Миколаєва 22 березня 1944 р. в Одесу ${ }^{128}$. Там пробули приблизно тиждень, розташувавшись на одній з дач у районі Аркадії ${ }^{129}$. За участь у боях проти Радянської армії напередодні евакуації з Одеси 15-20 співробітників були нагороджені «Залізним хрестом» II класу.

3 Одеси співробітники Миколаївського СД вирушили на машинах у м. Галац (Румунія), де вже не здійснювали ніяких операцій, а згодом штат майже повністю був розформований ${ }^{130}$. У Галаці частина особового складу розташовувалась у двоповерховому будинку, що раніше належав румунському пану. Там дислокувались вантажівки з речами, водії цих машин, офіцери та керівництво поліції безпеки та СД. Перекладачі та інші співробітники розмішувались в іншій будівлі - через одну вулицю. У місті перебували не більше двох місяців.

Звідти всі співробітники відправились у Будапешт (Угорщина). Керівництво СД їхало попереду. Коли колона наближалась до місця ночівлі, то офіцери СД вже перебували там. Туди ж прибували й інші співробітники СД. Тобто всі їхали не однією колоною, а групами, і кожна група рухалась самостійно до попередньо обумовленого місця ночівлі. На легкових машинах із керівництвом СД були водії Микола Сиволоб, Микола Барановський, Мясков, Шаповалов та ін. Відомо, що в період свого перебування в Угоршині колишні співробітники Миколаївського управління поліції безпеки та СД брали участь у відстоюванні пронімецьких інтересів під час воєнного перевороту

\footnotetext{
127 ГДА СБУ, ф. 11, оп. 1, спр. 1043, т. 1, ч. IV, арк. 47-49.

${ }_{128}$ САЗ УСБУ в Миколаївській області, ф. 5, оп. 1, спр. 13204, т. 2, арк. 135.

129 САЗ УСБУ в Миколаївській області, ф. 5, оп. 1, спр. 13204, т. 3, арк. 77 зв.

${ }_{130}$ САЗ УСБУ в Миколаївській області, ф. 5, оп. 1, спр. 13204, т. 2, арк. 196.
} 
Міклоша Хорті в липні-серпні 1944 р., а також сприяли приходу до влади в Угорщині нового прихильника Гітлера ${ }^{131}$.

Після Будапешта офіцери Миколаївського управління поліції безпеки та СД виїхали в район м. Брно (Чехословаччина) ${ }^{132}$. Долі інших співробітників СД склались по-різному. Автор встановив, що з частини співробітників, серед яких перебував і колишній перекладач Іван Бернгардт, був сформований взвод і в грудні 1944 р. переданий у розвідувальну частину дивізії «Мертва голова». На початку 1945 р. реформований підрозділ одразу направили на передову лінію фронту - лівий берег Дунаю, напроти м. Тульн в Австрії. 10 травня 1945 р. цей взвод потрапив у полон до американців, а пізніше був переданий у зону окупації радянських військ ${ }^{133}$.

Перекладач поліції безпеки та СД Євгеній Гопфауф служив після евакуації з Миколаєва в Одесі, Львові, Кракові. Згодом його направили в Італію в м. Верона у розпорядження шефа СС і поліції того міста, де разом з ним перебували його товариші по службі Зайферт i Майєр. Євгеній Гопфауф отримав призначення в табір італійських ув'язнених, що розташовувався на окраїні м. Больцано (Північна Італія). У цьому таборі С. Гопфауф служив шуцманом до квітня 1945 р. Начальником табору в Больцано був німець унтерштурмфюрер Тіто ${ }^{134}$.

Водій Миколаївського СД Микола Барановський в Будапешті потрапив у підпорядкування оберлейтенанта вермахта Вальтера Шмідта та під його керівництвом вивозив на вантажівці різні продукти харчування, інші цінності до ешелонів, що рухались з Угорщини до Німеччини. Разом з ним він і потрапив на територію Австрії. У березні 1945 р. багато військовослужбовців німецької армії перевдягались у цивільний одяг і розходились хто куди. Микола Барановський вчинив аналогічно. Перевдягнувся в одного бауера в цивільний одяг та пішов до м. Зальцбурга, у зону окупації американських військ. Там він перебував у таборі для переміщених осіб, де були росіяни, українці, німці-колоністи, тобто ті люди, які з тих чи інших причини не хотіли повертатись до СРСР. Можливо, Микола Барановський і уник би покарання, але орієнтовно в 1948 р. він через необережність потрапив до рук радянського командування. Це трапилось тоді, коли він разом з одним німцем Еріком Сайдлером із Зальцбурга поїхав до

\footnotetext{
131 САЗ УСБУ в Миколаївській області, ф. 5, оп. 1, спр. 13204, т. 3, арк. 77-79.

132 САЗ УСБУ в Миколаївській області, ф. 5, оп. 1, спр. 13204, т. 3, арк. 80.

${ }_{133}$ САЗ УСБУ в Миколаївській області, ф. 5, оп. 1, спр. 13204, т. 3, арк. 196-197.

134 САЗ УСБУ в Миколаївській області, ф. 5, оп. 1, спр. 13204, т. 2, арк. 412-413.
}

м. Лінц. Там вони мали допомогти переправити до Зальцбурга товари двом спекулянтам, тобто хотіли підзаробити. У буфеті вони відзначили угоду, і Микола Барановський перепив так, що навіть не пам'ятав, яким чином потрапив до радянської зони окупації, де його вранці розбудив капітан Радянської армії ${ }^{135}$.

Перший шеф поліції безпеки та СД генеральної округи «Миколаїв оберштурмфюрер СС Ганс Занднер був страчений на шибениці 17 січня 1946 р., на тій же Базарній площі (на розі вул. Соборної та просп. Центрального) у Миколаєві, де в січні та березні 1942 р. він керував стратою цивільних громадян і місцевих підпільників. Разом з ним на лаві підсудних, а також засудженими до страти через шибеницю були й інші злочинці: воєнний комендант Миколаєва генераллейтенант Г. Вінклер (страчений), начальник управління жандармерії генеральної округи «Миколаїв» майор М. Бютнер (страчений), начальник жандармерії Херсона капітан Ф. Канцлер (20 років каторги), начальник жандармерії Березнегуватського району Миколаївької області майор Р. Міхель (страчений), начальник охоронної поліції Миколаєва майор Ф. Вітцлеб (страчений), капітан Г. Шмалє (заступник Ф. Вітцлеба, страчений), фельдфебель польової жандармерії Р. Берг (страчений), оберєфрейтор 783 охоронного батальйону Й. Хапп (страчений $)^{136}$.

Таким чином, за допомогою нещодавно виявлених матеріалів архіву Служби безпеки України вперше вдалось детально дослідити штат і структуру Управління поліції безпеки та СД генеральної округи «Миколаїв», його активну роль у масовому терорі проти місцевого населення у період з 2 листопада 1941 до 22 березня 1944 р.

Автору вдалось з'ясувати й ряд нових прізвищ співробітників айнзатцкоманди 5, які з оберштурмфюрером СС Гансом Занднером ще до прибуття до Миколаєва були присутні під час масового знищення єврейського населення в Бабиному Яру 29-30 вересня 1941 р., а згодом у тому ж місці, у першій декаді жовтня окремі представники згаданого підрозділу під керівництвом Г. Занднера безпосередньо здійснювали масові розстріли євреїв та військовополонених.

Аналіз етнічного складу Управління поліції безпеки та СД показує, що більшість його співробітників - це імперські німці, а також фольксдойче (місцеві німці). Усі керівні посади займали тільки імперські німці, а фольксдойче використовувались як перекладачі (помічники слідчих), вахманів СД, водіїв, охоронців в’язниці СД та ін. Тільки V

$\overline{135}$ САЗ УСБУ в Миколаївській області, ф. 5, оп. 1, спр. 13204, т. 3, арк. 79-80.

${ }^{136}$ САЗ УСБУ в Миколаївській області, ф. 5, оп. 1, спр. 13262, арк. 1-2; 267-268. 
відділ поліції безпеки та СД (Кріпо) мав штат слідчих, який складався з українців та росіян. Місцеве українське та російське населення також використовувалось на посадах штатних рядових поліцейських, водіїв, охоронців в’язниці та концтабору СД для цивільного населення, водіїв, нештатних таємних агентів та ін.

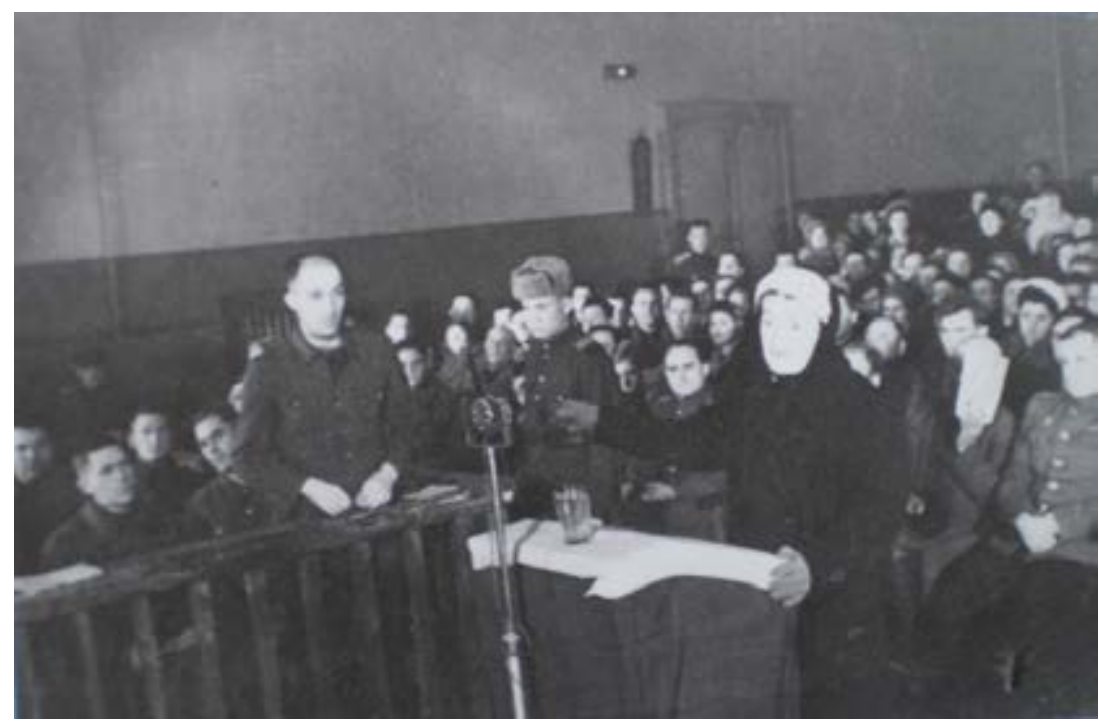

Допит свідка Е. Барг (ініціали російською) - дружини відомого лікаря 3. Барга, якого розстріляли у складі 20 лікарів та 22 членів їх родин на початку квітня 1942 р. за наказом та у присутності Г. Занднера. Судовий процес у справі злочинів нацистських окупантів на території Миколаївської області, м. Миколаїв, січень 1946 p. ${ }^{137}$

Проведення масштабного терору було б неможливим без створення розгалуженої агентурної мережі, до якої вербувалось цивільне населення (фольксдойче, українці, росіяни), колишні радянські військовополонені, зрадники із представників місцевого підпілля. Мотивація співробітництва місцевого населення з поліцією безпеки та СД була різною. Частина активно співпрацювала з власної ініціативи через свої політичні погляди (наприклад, репресовані в радянських період, місцеві німці, які автоматично отримували особливий статус). Інші служили з метою уникнути депортації до Німеччини, через бажання вижити чи отримати кар'єрний зріст у період воєнного лихоліття. Частина населення залучалась до співробітництва насильно через погрози, шантаж та ін.

\footnotetext{
${ }_{137}$ ДАМО, фотодокументи, оп. 1, од. зб. 20346.
}

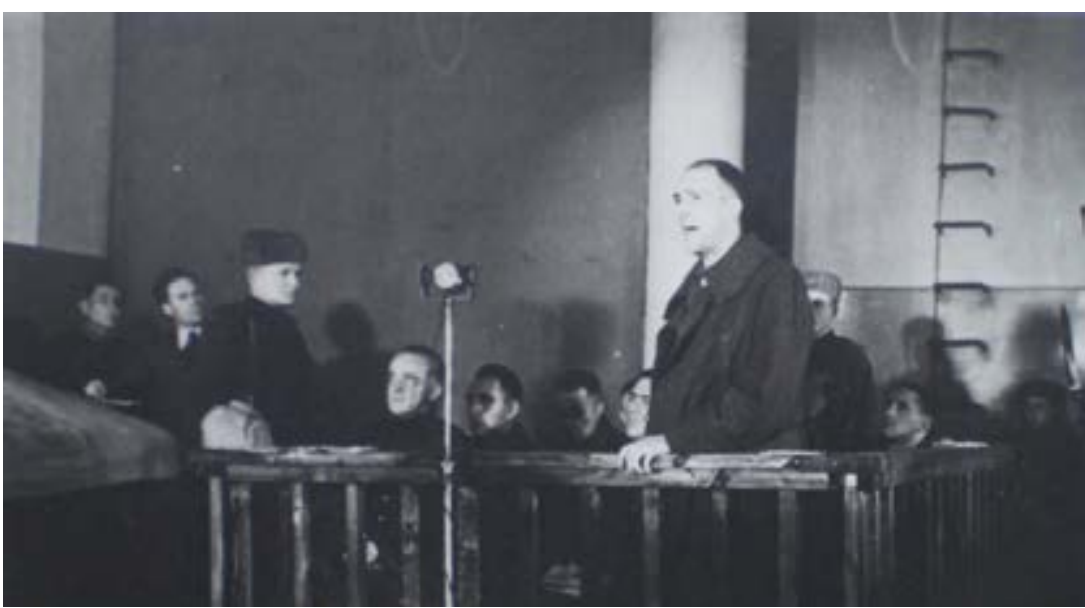

Допит колишнього шефа Управління поліції безпеки та СД генеральної округи «Миколаїв оберштурмфюрера СС Ганса Занднера. Судовий процес у справі злочинів нацистських окупантів на території Миколаївської області, м. Миколаїв, січень 1946 p. ${ }^{138}$

Головними жертвами терору в досліджуваному регіоні стали єврейське та ромське населення, представники радянського та націоналістичного підпілля, члени комуністичної партії, психічно хворі, частина радянських військовополонених, пересічні мешканці, які з тих чи інших причин порушували «новий порядок».

Основними напрямками терору були арешти, тортури, масові розстріли, показові страти на шибениці, утримання населення з різними термінами відбування покарання в центральній в’язниці СД, у концтаборі поліції безпеки та СД для цивільного населення «Водокачка», а також депортація заарештованих для подальшого відбування покарання в концтабори Німеччини, зокрема, Бухенвальд і Равенсбрюк. Вдалось встановити місця і процедуру розстрілів деяких етнічних груп, персоніфікувати безпосередніх учасників вказаних злочинів.

Введені до наукового обігу світлини та архівні матеріали дають більш широке уявлення про масштаби злочинів конкретних представників гітлерівських військ в Україні, сприятимуть подальшим науковим пошукам у дослідженні тематики Голокосту, місцевого підпільно-партизанського руху, депортації населення на рабську працю до концтаборів Німеччини та ін.

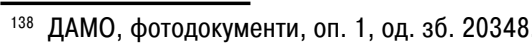




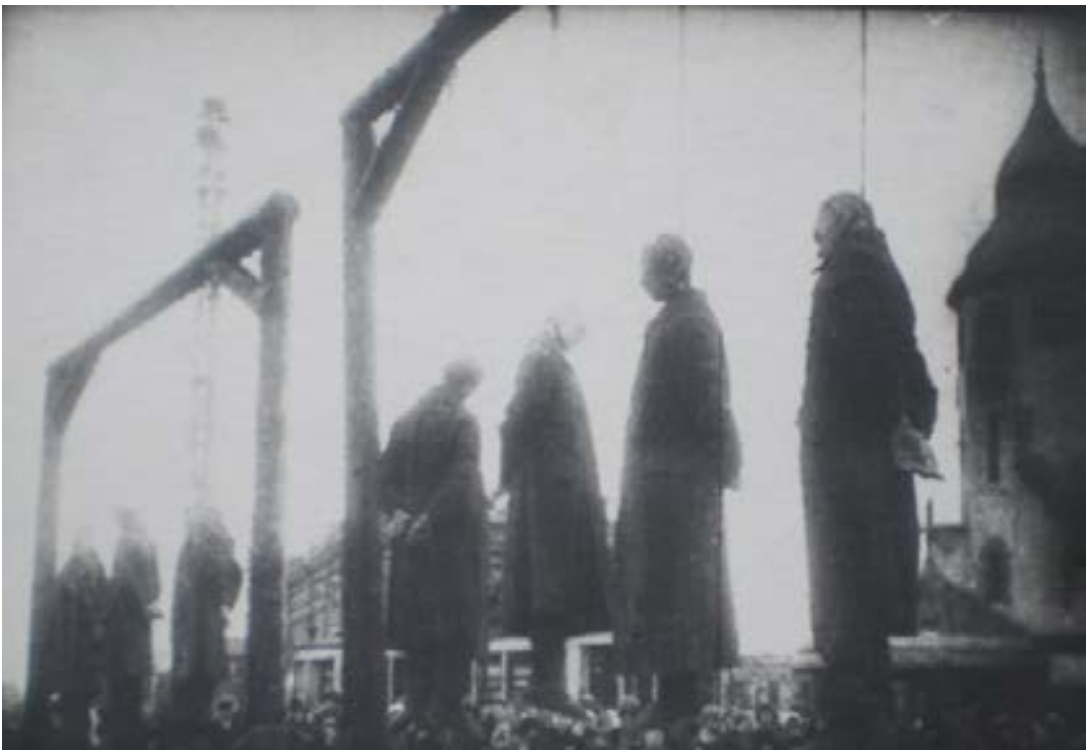

Страчені нацистські військові злочинці, м. Миколаїв, 17 січня 1946 p. ${ }^{139}$

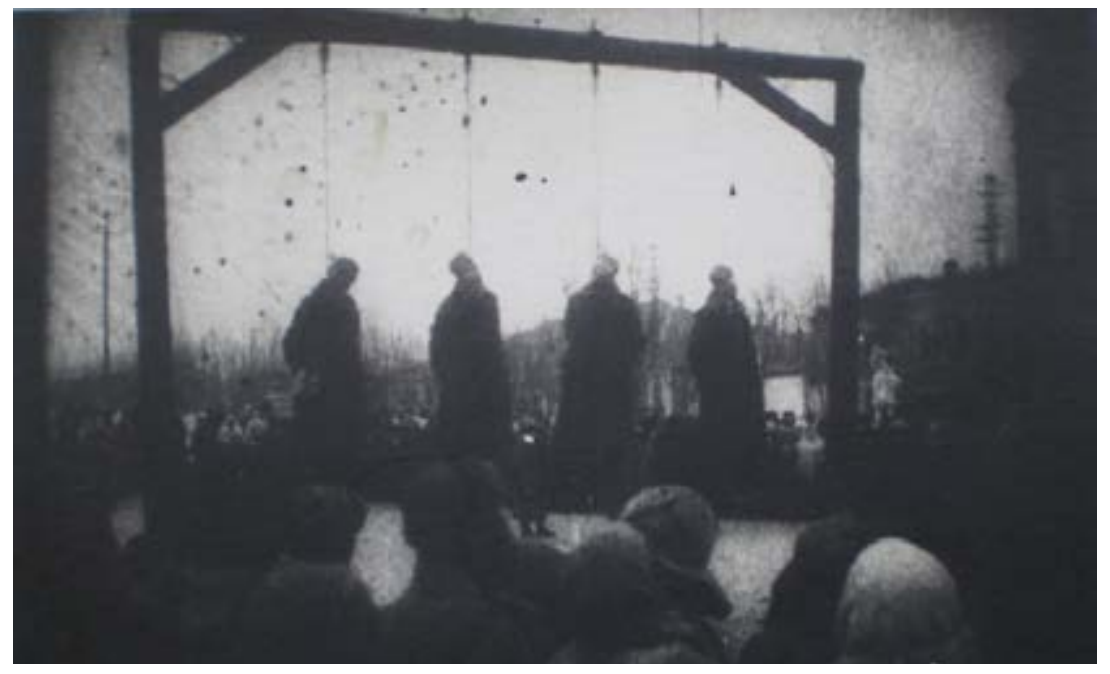

Страчені нацистські військові злочинці, м. Миколаїв, 17 січня 1946 р. ${ }^{140}$

${ }_{139}$ ДАМО, фотодокументи, оп. 1, од. зб. 6509

140 ДАМО, фотодокументи, оп. 1, од. зб. 6512.
Варто зауважити, що будівлі колишньої штаб-квартири Управління поліції безпеки та СД генеральної округи «Миколаїв» й досі не входять до міського меморіального простору, попри те, що цей квартал став місцем травми, загибелі чи останньою відправною точкою перед стратою для більшості учасників місцевих рухів Опору, пересічних корінних мешканців та представників етнічних меншин. Стіни споруд, світлини яких розміщені у статті, не містять жодної пам'ятної дошки, що нагадували б про трагічні сторінки воєнного лихоліття, страшного минулого нашого краю.

Anatolii Pogorielov

\section{THE FACE OF DEATH: TERROR BY THE SECURITY POLICE AND SD AGAINST THE POPULATION OF THE GENERAL DISTRICT "MYKOLAIV"}

The article examines in detail for the first time the structure and personnel of the Department of Security Police and SD of the General District Mykolaiv and its role in large-scale terror against the civilian population of the region. The study enumerats the names of command level and rank-and-file personnel directly involved in arrests, tortures, and convoys during mass shootings and demonstrative executions. It also describes the basic recruitment methods as well as the mechanism for establishing a branched network of agents comprised of local collaborators. In the article, the locations and procedures of certain executions of the Jewish and Roma population are specified. Published here for the first time are the photograph of SS-Sturmbannführer Dr. Leopold Spann, the Second Chief of the Security Police and SD of General District "Mykolaiv", and portraits of other personnel of the Security Police and SD. The article presents a schematic drawing of the location and layout of the main buildings of the Security Police headquarters in Mykolaiv and schemes of the locations of mass executions. Compiled here is also the list of Sonderkommando members engaged in liquidating the traces of the Security Police and SD crimes. The further routes taken by Security Police and SD employees after their evacuation from Mykolaiv in March of 1944 are described.

Keywords: Mykolaiv, Security Police and SD, terror, civilian population, Resistance movement, Jewish and Roma population, the Holocaust, collaboration.

\section{Bibliography}

Chuev, Sergej. Specsluzhby Tret'ego Rejha.Kniga II. Sankt-Peterburg: Izdatel'skij dom «Neva»; Moskva: «OLMA-PRESS Obrazovanie», 2003. 
Chunihin, Vladimir. Licom k licu s SD. Odessa: Majak, 1987.

Chunihin, Vladimir. Nevidimoj armii dobrovol'cy. Nikolaev: KP «Mykolaivska oblasna drukarnia», 2004.

Dereiko, Ivan. «Mistsevi dopomizhni struktury ta viiskovi formuvannia politsii bezpeky ta SD na terenakh Raiskhkomisariatu "Ukraina": 19411944.» Storinky voiennoi istorii Ukrainy 12 (2009): 177-184.

Gol'denberg, Mihail, red. Sud'by evreev Nikolaevshhiny v period Velikoj Otechestvennoj vojny 1941-1945 gg. Nikolaev: Izdatel’ P. N. Shamraj, 2012.

Gorburov, Evgenij, i Kirill Gorburov. Nikolaevskij «Njurnberg». Sudebnyj process po delu o nemecko-fashistskih zverstvah v g. Nikolaeve i Nikolaevskoj oblasti 10-17 janvarja 1946 goda. Nikolaev: Ilion, 2016.

Horburov, Yevhen. «Pidpilnyi ta partyzanskykh rukh na terytorii Mykolaivshchyny v roky Velykoi Vitchyznianoi viiny.» U Mykolaivshchyna v roky Velykoi Vitchyznianoi viiny: 1941-1944 rr. (Do 60-richia vyzvolennia oblasti vid nimetsko-rumunskykh okupantiv). Mykolaiv: Kvit, 2004.

Hrynevych, Vladyslav, i Pavlo-Robert Magochii, red. Babyn Yar: Istoriia ta pamiat. Kyiv: Dukh i Litera, 2017.

Kruglov, Aleksandr. Bez zhalosti i somnenija: dokumenty o prestuplenijah operativnyh grupp i komand policii bezopasnosti i SD na vremenno okkupirovannoj territorii SSSR v 1941-1944 gg.Ch. IV. Dnepropetrovsk: Centr «Tkuma»; Lira LTD, 2010.

Shytiuk, Mykola. «Znyshchennia yevreiskoho naselennia v Pivdennii chastyni reikhskomisariatu "Ukraina".»U Materialy Mizhnarodnoi naukovo-praktychnoi konferentsii «Istorychna pamiat pro viinu ta Holokost», Kyiv, 28-30 veresnia 2012 r., 195-215. Dnipropetrovsk: Tsentr «Tkuma», 2013

Vasyliev, Valerii, Natalia Kashevarova, Olena Lysenko, Mariia Panova, i Roman Podkur, avt.-ukl. Nasylstvo nad tsyvilnym naselenniam Ukrainy. Dokumenty spetssluzhb. 1941-1944. Kyiv: Vydavets V. Zakharenko, 2018.

\section{Archives}

Derzhavnyi arkhiv Mykolaivskoi oblasti (DAMO). F. R. 5859, op. 1, spr. 9319; fotodokumenty, op. 1, od. zb. 6104, 6509, 6512, 20346, 20348.

Haluzevyi derzhavnyi arkhiv Sluzhby bezpeky Ukrainy (HDA SBU). F. 11, op. 1, spr. 1043, t. 1, 11.

Sektor arkhivnoho zabezpechennia Upravlinnia Sluzhby bezpeky Ukrainy v Mykolaivskii oblasti (SAZ USBU v Mykolaivskii oblasti). F. 5, op. 1 , spr. 7945; 13204, t. 2, 3, 6, 7; 13262.
ДОІ 10.33124/hsuf.2019.11.05

Олена Корзун

\section{СПІВРОБІТНИЦТВО НІМЕЦЬКИХ ТА УКРАЇНСЬКИХ ВЧЕНИХ ПІД ЧАС ДРУГОЇ СВІТОВОЇ ВІЙНИ ЗА МЕМУАРАМИ НІМЕЦЬКОГО БОТАНІКА, ПРОФЕСОРА ГЕНРІХА ВАЛЬТЕРА (1898-1989)}

У статті за мемуарами всесвітньо відомого біолога, вченого в галузі фітогеографії Генріха Вальтера (1898-1989) «Сповідь еколога» аналізується сприйняття німецьким вченим наукового життя на окупованих українських землях часів Другої світової війни, відносини з українськими науковиями. Доля Г. Вальтера тісно пов'язана з українськими землями - він тут народився, провів перші двадиять років свого життя, а згодом повернувся під час Другої світової війни. Мемуари німецького вченого вітчизняні та зарубіжні науковці використовують як джерело для вивчення історіі науки, однак поза увагою залишається дослідження його оцінки подій суспільного, наукового життя часів Другої світової війни, взаємовідносин з українськими фахівцями, які залишились на окупованих землях.

Після початку німецької воєнної експансії відбулись зміни в завданнях сільськогосподарських досліджень німецької аграрної науки. Війна надала можлливість підпорядкувати всі сільськогосподарські наукові установи та насіннєві станції на східних окупованих територіях та привласнити результати їхньої наукової роботи. Одночасно вивчення та включення генетичних ресурсів та наукового потенціалу окупованих територіі в сільськогосподарську дослідну справу Німеччини мало слугувати «свободі харчування» для німців.

У 1942-1943 рр. українські землі стали своєрідним дослідним майданчиком для багатьох німецьких науковців. Воєнний період «за Вальтером» сприймається як низка можсливостей для наукового зростання німецького науковия - освоєння нових територій, знайомство з іншими науковими школами, вченими, внесок у наукове забезпечення ефективного використання сільськогосподарського потенціалу окупованих земель. Але з іншого боку - ие можливість продемонструвати своє служіння державі через практичне використання набутих наукових знань як фахівия, знавия місцевих природничих умов окупованих земель, російської мови тощо. Незважсаюч на більш як сорокарічний період, що розділяє описані події з датою публікації мемуарів, автор продовжує симпатизувати нацистській політиці в багатьох питаннях. 